\title{
Interactions of Human Melanocortin 4 Receptor with Non Peptide and Peptide Agonists ${ }^{\dagger}$
}

\author{
Irina D. Pogozheva§,, , Biao-Xin Chaill,, , Andrei L. Lomize§, Tung M. Fong ${ }^{\ddagger}$, David H. \\ Weinberg $\ddagger$, Ravi P. Nargund $\ddagger$, Michael W. Mulholland $\|$, Ira Gantz $\ddagger$, and Henry I. Mosberg $\S$, \\ $\S$ Department of Medicinal Chemistry, College of Pharmacy, University of Michigan, Ann Arbor, MI 48109 \\ \|Department of Surgery, School of Medicine, University of Michigan, Ann Arbor, MI 48109 \\ \$Merck \& Co., Inc., Rahway, NJ 07065-0900
}

\section{Abstract}

\begin{abstract}
Specific interactions of human melanocortin-4 receptor (hMC4R) with its non-peptide and peptide agonists were studied using alanine-scanning mutagenesis. The binding affinities and potencies of two synthetic small-molecule agonists (THIQ, MB243) were strongly affected by substitutions in transmembrane $\alpha$-helices (TM) 2, 3, 6, and 7 (residues Glu ${ }^{100} \mathrm{Asp}^{122}$, Asp ${ }^{126}$, Phe ${ }^{261}$, $\mathrm{His}^{264}$, $\mathrm{Leu}^{265}$, and $\mathrm{Leu}^{288}$ ). In addition, I129A mutation primarily affected binding and potency of THIQ, while F262A, W258A, Y268A mutations impaired interactions with MB243. By contrast, binding affinity and potency of the linear peptide agonist NDP-MSH were substantially reduced only in D126A and H264A mutants. 3D models of receptor-ligand complexes with their agonists were generated by distance geometry using the experimental, homology-based, and other structural constraints, including interhelical H-bonds and two disulfide bridges $\left(\mathrm{Cys}^{40}{ }_{-} \mathrm{Cys}^{279}\right.$, $\mathrm{Cys}^{271}$ $\mathrm{Cys}^{277}$ ) of hMC4R. In the models, all pharmacophore elements of small-molecule agonists are spatially overlapped with the corresponding key residues $\left(\mathrm{His}^{6},{ }_{\mathrm{D}}-\mathrm{Phe}^{7}, \operatorname{Arg}^{8}\right.$ and $\operatorname{Trp}^{9}$ ) of the linear peptide: their charged amine groups interact with acidic residues from TM2 and TM3, similar to $\mathrm{His}^{6}$ and $\mathrm{Arg}^{6}$ of NDP-MSH; their substituted piperidines mimic $\operatorname{Trp}^{9}$ of the peptide and interact with TM5 and TM6; while the ${ }_{\mathrm{D}}$-Phe aromatic rings of all three agonists contact with Leu ${ }^{133}$, $\operatorname{Trp}^{258}$, and $\mathrm{Phe}^{261}$ residues.
\end{abstract}

\begin{abstract}
Melanotropins, which include melanocyte-stimulating hormones $(\alpha-, \beta-$, and $\gamma-\mathrm{MSH})$ and adrenocorticotropic hormone (ACTH), are the products of proteolytic cleavage of the 31-36

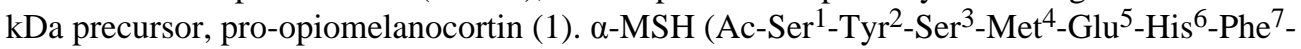
Arg ${ }^{8}$-Trp ${ }^{9}-\mathrm{Gly}^{10}{ }^{10} \mathrm{Lys}^{11}-\mathrm{Pro}^{12}-\mathrm{Val}^{13}-\mathrm{NH}_{2}$ ) shares with all melanotropins the central core tetrapeptide 'His ${ }^{6}-\mathrm{Phe}^{7}-\mathrm{Arg}^{8}-\mathrm{Trp}^{9}$ ', which is essential for its biological activity (2). These neuropeptides exert their function through five subtypes of melanocortin receptors (MCRs), which have been cloned and characterized (1,3). MCRs belong to the G protein-coupled receptor (GPCR) superfamily (4) and are positively coupled to cAMP-generation by adenylate cyclase via the stimulatory Gs-proteins. They are involved in regulation of multiple physiological functions, such as pigmentation (MC1R), adrenal cortical steroidogenesis
\end{abstract}

\footnotetext{
${ }^{\dagger}$ This work was supported by NIH grants DK054032 (I.G., M.W.M.), DA03910 (H.I.M.), and the University of Michigan Gastrointestinal Peptide Research Center (NIH Grant P30DK34933)

$\perp_{\text {Contributed equally to this work }}$

* Corresponding author: Department of Medicinal Chemistry 428 Church St Ann Arbor, MI 48109-1065 Phone: (734) 764-8117 Fax: (734) 763-5595 Email: him@umich.edu

Supporting Information Available:Table of receptor type-specific distance constraints for the distance geometry refinement of the model of the active conformation of MC4R. This material is available free of charge via the Internet at http://pubs.acs.org.
} 
(MC2R), exocrine secretion (MC5R), energy homeostasis, penile erection (MC3R and MC4R) and many others $(1,5,6)$.

The MC4R subtype is regarded as a potential drug target, because it is involved in feeding and sexual behavior (7-9). Mammals with a defective MC4R gene, which is expressed in the brain, are characterized by obese phenotype and increased food intake (10-12). AGRP acts as an inverse agonist, reducing the elevated basal activity of MC4R (13-17). Pharmacological studies indicate that activation of the MC4R in rodents modulates erectile function (9). Consequently research efforts have been focused on the development of potent and MC4R-selective agonists as potential anti-obesity drugs or as treatments for sexual dysfunction $(18,19)$. On the other hand, MC4R antagonists that block the satiety-inducing effect of $\alpha$-MSH could be helpful for treatment of anorexia or cancer cachexia (20).

Recently a number of small-molecule MC4R agonists and antagonists have been synthesized using "privileged structures" formerly employed in other GPCR ligands $(21,22)$. In particular, THIQ and MB243 (Figure 1) were identified as potent MC4R agonists with >100 fold selectivity over MC1R, MC3R and MC5R $(18,19)$.

The binding affinities, potencies, and selectivities of the ligands can be interpreted, understood, and applied for rational drug design only in the context of 3D structures of receptor-ligand complexes. However, among all GPCRs, a crystal structure has been determined only for rhodopsin, and only in its inactive state $(23,24)$. In the absence of direct crystallographic data, other GPCRs can be modeled simply by homology from the rhodopsin template. Indeed, homology modeling is a well-established technique (25) that currently works best for GPCRs (26). However, several challenges remain. First, the active, agonist-bound conformation of GPCRs differs from the inactive state, especially in the position of transmembrane helix (TM) 6 (27). Second, the sequence alignment of rhodopsin and other GPCRs is not obvious in the region of the nonregular loops and at helical distortions, such as the $\alpha$-aneurisms (the insertion of an extra-residue in a helical turn)) present in TM2 and TM5, in the rhodopsin structure, which may be absent in other GPCRs. Finally, ligand docking is a complicated problem (28).

These difficulties can be resolved by obtaining additional experimental data probing interactions of the specific receptors and their ligands and by using distance geometry calculations to assist homology modeling by satisfying target receptor-specific experimental and other structural constraints (29-32). The experimental constraints can be determined using a variety of techniques $(31,32)$. For example, the experimental studies of the effects of numerous mutations on binding of natural antagonists to hMC4R allowed modeling of the complex of the inactive conformation of hMC4R with AGRP and agouti protein (33). Moreover, we have recently calculated the model of active conformation of the $\mu$-opioid receptor, using distance constraints from the crystal structure of the inactive conformation of rhodopsin (24) together with a large set of experimental constraints that are compatible with active states in several GPCRs (31). This model of the active conformation of $\mu$-receptor can be used as a structural template for the modeling of other rhodopsin-like GPCRs that apparently share common activation mechanism and similar active conformations $(34,35)$.

In the present study, mutagenesis data are used similarly to model the active state of the hMC4R receptor in complex with agonists by distance geometry calculations with experimental, hydrogen-bonding, and homology-based constraints. More specifically, we have identified hMC4R residues required for activity of two small-molecule, peptidomimetic agonists, THIQ and MB243, by examining the effects of thirteen mutations in the TM domain on agonist binding and ligand-induced receptor-mediated cAMP accumulation. A homology model of the active hMC4R state was generated, based on our previous experimental and modeling studies of the inactive hMC4R (33) and of the $\mu$-opioid receptor in the active state (31) and was used 
for docking of the two small-molecule agonists into the receptor model, guided by our mutagenesis data. Subsequently, a complex of hMCR4 with its linear peptide agonists, $\alpha$-MSH and NDP-MSH (36) was calculated assuming the structural overlap of pharmacophoric elements of peptide and nonpeptide ligands.

\section{Experimental Procedures}

\section{Cell transfection and culture}

The wild type hMC4R and all mutants were expressed from the eukayotic expression vector pcDNA3.1 (Invitrogen, Carlsbad, CA). The hMC4R mutants had previously been constructed during the course of other studies $(33,37,38)$ using Quick Change Site-Directed Mutagenesis Kit (stragene, La Jolla, CA). The presence of desired mutations and the integrity of the entire receptor sequence were confirmed by sequencing performed in the University of Michigan Biochemistry core. Large scale plasmid preparations were made using Qiagen Plasmid Maxi Kit (Qiagen, Valencia, CA). HEK 293 cells were transiently transfected in a $10 \mathrm{~cm}$ dish with $5 \mu \mathrm{g}$ of receptor plasmid DNA using $20 \mu \mathrm{l}$ of Lipofectamine Reagent (Invitrogen, Carlsbad, CA). After 24 hours the cells were trypsinized and aliquoted into 24-well plates and grown in Dulbecco's modified Eagles medium (DMEM) containing $4.5 \mathrm{~g} / 100 \mathrm{ml}$ glucose, $10 \%$ fetal calf serum, $1 \mathrm{mM}$ sodium pyruvate.

\section{Ligand binding}

${ }^{125}$ I-NDP-MSH was prepared by the chloramine-T method as previously described (38). NDPMSH was purchased from Peninsula Laboratories, Inc. The specific activity of ${ }^{125} \mathrm{I}-\mathrm{NDP}-\mathrm{MSH}$ was $618-727 \mathrm{Ci} / \mathrm{mmol}$. Binding experiments were performed using $0.35 \mathrm{nM}$ of radioligand. Binding assays were performed as previously described (38). $3 \times 10^{5}$ cells were planted on 24 well plates and cultured for $\sim 17-19 \mathrm{~h}$ before the experiments. IC $_{50}$ values of NDP-MSH were determined from the inhibition of radioligand binding by increasing concentrations of nonlabeled ligand. The highest non-labeled ligand concentration used was $10^{-6} \mathrm{M}$. Nonspecific binding was determined in the presence of cold ligand at $10^{-5} \mathrm{M}$. Nonspecific binding was less than $5 \%$ of specific binding. $\mathrm{IC}_{50}$ values are reported as the mean \pm standard error. To calculate $\mathrm{K}_{\mathrm{i}}$ values the equation $\mathrm{K}_{\mathrm{i}}=\mathrm{K}_{\mathrm{d}}=\mathrm{IC}_{50}$ - [radioligand] was used (39). Experiments were repeated at least three times using duplicate wells on different days.

\section{3', 5'- adenosine monophosphate (cAMP) measurement}

cAMP measurements were performed using a competitive binding assay kit (TRK 432, Amersham; Arlington Heights, IL) as previously described (38). $2 \times 10^{5}$ cells were planted on 24 well plates and cultured for $\sim 17-19 \mathrm{~h}$ before the experiments. THIQ (18) and MB243 (19) were synthesized by Merck \& Co., Inc. The mean value of the data was fit to a sigmoid curve with a variable slope factor using the non-linear least squares regression in Graphpad Prism (Graphpad Software). $\mathrm{EC}_{50}$ values are reported as mean \pm the standard error. Experiments were repeated at least three times using duplicate wells on different days.

\section{Modeling of melanocortin receptor-agonist complexes}

The inactive state of hMC4R (SwissProt accession code P32245) has recently been modeled from the rhodopsin crystal structure (24) by iterative distance geometry refinement (33), an approach described and tested previously $(29-31,40)$. This modeled structure of hMC4R remained very close to the rhodopsin template (r.m.s.d. $1.31 \AA$ for $198 \mathrm{C} \alpha$-atoms of TM domain). The homology modeling of the agonist-bound state of hMC4R (residues 29-321), was accomplished here similarly using the program DIANA (41), which calculates a set of structures satisfying the imposed distance and angle constraints. Two different structural templates were used: the model of the inactive conformation of hMC4R (33) and the model of 
the active conformation of $\mu$-opioid receptor, which we have previously described (31). The template of the active conformation of $\mu$-opioid receptor, which deviates from the rhodopsin structure mostly in the position of TM6 (r.m.s.d. $2.2 \AA$ for $212 \mathrm{C} \alpha$-atoms of TM domain), was chosen because it adequately reproduces helical shifts, and especially the large movement of TM6 upon receptor activation. All constraints for the seven- $\alpha$-helical TM domain were taken from the active $\mu$-receptor model, while the constraints for loops were taken from the model of inactive hMC4R. Based on mutagenesis and modeling results we have previously proposed that in MCRs a $\beta$-hairpin is formed in EL1, as in bacterial rhodopsins, an additional short $\beta$ strand in the N-terminal segment is attached to EL3 by a disulfide bond between Cys ${ }^{40}$ and $\mathrm{Cys}^{279}$, while another important disulfide bond, Cys ${ }^{271}{ }_{-C y s}{ }^{277}$, connects EL3 to TM6 (33). An alterative conformation of EL3 was also used with TM6 extended by three residues at the extracellular end. Sequence alignment of MCRs and rhodopsin (Figure 2) has been described previously (33). The alignment assumes the disappearance of an $\alpha$-aneurism in TM2 that is present in rhodopsin, but conservation of the $\alpha$-aneurism found in TM5 of the rhodopsin crystal structure, consistent with previous mutagenesis studies (33).

During distance geometry calculations of the ligand-free receptor with DIANA (41), the spatial positions of all TM helices were restrained using the following upper distance constraints (specified in Supplemental Materials): (a) the $C^{\beta} \ldots C^{\beta}$ distances from the templates with allowed deviations of $0.5 \AA$, (b) a set of $54 \mathrm{H}$-bonds specific for hMC4R (O... , N...O distances of $2.9 \AA$, ), and (c) constraints for two disulfide bonds $\left(S \gamma \ldots S^{\gamma}, C^{\beta} \ldots C^{\beta}, C^{\beta} \ldots S^{\gamma}\right.$ distances of 2.04, 4.20, $3.05 \AA$, respectively), linking $\mathrm{Cys}^{40}-\mathrm{Cys}^{279}$ and $\mathrm{Cys}^{271}-\mathrm{Cys}^{277}$; (c) constraints (N... O distances of $3.5 \AA$ ) for two artificial $\mathrm{Zn}^{2+}$-binding centers previously designed in hMC4R (42) between TM2 and TM3, I104H-Asp ${ }^{122}$ and I125H-Glu ${ }^{100}$, which enabled receptor activation by $\mathrm{Zn}^{2+}$-ions. The implementation of these constraints retained the structure of the templates, but allowed small spatial adjustments of alla-helices during the calculations. The dihedral angles of receptor residues were generally taken as in the template, with allowed deviations of $30^{\circ}$. Side chain rotamers were taken from the model of the inactive hMC4R (33), with the exception of several residues that rotate upon receptor activation (31), such as the conserved Asp ${ }^{126}$, Leu ${ }^{140}, \operatorname{Arg}^{147}, \mathrm{Tyr}^{212}, \operatorname{Trp}^{258}$ and several additional residues $\left(\mathrm{Leu}^{133}, \mathrm{Arg}^{165}, \mathrm{Phe}^{184}, \mathrm{Met}^{208}, \mathrm{Met}^{215}\right)$. The standard target function weights and minimization protocol were applied (41). The pairwise r.m.s.d. between the ten best calculated models of the hMC4R was $<0.7 \AA$ (for $282 \mathrm{C} \alpha$-atoms).

3D-structures of the agonist ligands THIQ and MB243 were generated with QUANTA (Accelrys), and low-energy conformers of the ligands (within $3 \mathrm{kcal} / \mathrm{mol}$ of the lowest energy conformation) were used for docking. Both ligands were first docked manually into the binding pocket of hMC4R to satisfy the following criteria: (1) a similar spatial arrangement of common pharmacophore groups in THIQ and MB243; (2) interaction of most functionally important groups of the ligands (especially, the central aromatic ring and $\mathrm{N}$-terminal $\mathrm{N}^{+}$group) with the corresponding receptor residues found to be most important for binding of the small molecule agonists (Glu ${ }^{100}, \mathrm{Asp}^{122}, \mathrm{Phe}^{261}$, and $\mathrm{His}^{264}$ ), as described in Results; (3) minimization of steric overlaps, and maximization of receptor-ligand $\mathrm{H}$-bonds and ionic and aromatic-aromatic interactions (conformers of several side-chains in the binding pocket were also adjusted). The structures of the complexes were then refined using the standard docking tool (DOCK) from QUANTA.

Large linear peptide agonists, NDP-MSH and $\alpha$-MSH, were included in the distance geometry calculations together with the receptor. Therefore, separate modeling of the isolated peptides and their docking was not required. The following types of constraints were used for the complex: (1) those within the receptor, taken exactly as in the ligand-free form (above); (2) 7 $\mathrm{H}$-bonds between the receptor and ligand identified in the initial model of the complex and during its iterative refinement (see Results); (3) $C^{\beta}-C^{\beta}$ upper limit constraints between ligand 
residues 4-10 and 5-10 of 4.5 and 7.5 $\AA$, respectively, that correspond to 4-10 disulfide and $5-10$ lactam bridges in the highly potent $\alpha$-MSH analogues $\left[\mathrm{Cys}^{4}-\mathrm{Cys}^{10}\right]-\alpha-\mathrm{MSH}(43)$ and MTII (Ac-Nle ${ }^{4}-\mathrm{cyclo}\left[\mathrm{Asp}^{5}\right.$, Lys $\left.\left.{ }^{10}\right] \alpha-\mathrm{MSH}(4-11) \mathrm{NH}_{2}\right)$ (44), respectively; and (4) torsion angle constraints in the central portion of the peptides ( $\mathrm{His}^{6}{ }_{-} \mathrm{LD}-\mathrm{Phe}^{7}-\mathrm{Arg}^{8}{ }^{-} \operatorname{Trp}^{9}$ ), chosen to mimic the bound conformers of the small-molecule agonists determined as described above. Side chain conformers of $\mathrm{His}^{6}\left(x 1 \sim-60^{\circ}\right)$ and $(\mathrm{L}, \mathrm{D}) \mathrm{Phe}^{7}\left(x 1 \sim 180^{\circ}\right)$ were chosen to mimic orientations of ${ }_{\mathrm{D}}$-Tic and $\mathrm{D}_{\mathrm{D}}$-Phe aromatic rings of THIQ. The iterative distance geometry refinement removed steric overlaps and maximized the number of $\mathrm{H}$-bonds between the receptor and ligands. Final energy minimization of all hMC4R-agonist complexes was performed using the CHARMm (45) potential with $\varepsilon=10$, and using the adopted-basis NewtonRaphson method (50 iterations).

\section{Results}

\section{Interactions of agonists with $\mathrm{hMC} 4 \mathrm{R}$ residues}

In order to understand how agonists interact with hMC4R, we studied the effects of point mutations on the binding affinity and potency of the peptide agonist NDP-MSH and two smallmolecule agonists, THIQ and MB243. Alanine-scanning mutagenesis was done in thirteen positions in the area of the putative ligand binding pocket $(16,33,37,38,46)$, whose mutation has been shown to affect binding of linear peptide agonists to MC4R and MC1R $(37,38,46)$. The mutated residues include $\operatorname{Trp}^{258}$, which is highly conserved in rhodopsin-like GPCRs and is presumed to be involved in activation mechanism (31), five residues that are generally conserved in MCRs $\left(\mathrm{Glu}^{100}\right.$, Asp ${ }^{122}$, Asp ${ }^{126}, \mathrm{Phe}^{261}, \mathrm{H}^{264}$ ), four residues conserved in most MCRs, except MC2R (Phe ${ }^{184}, \mathrm{Phe}^{262}$, $\mathrm{Leu}^{265}$, Leu ${ }^{288}$ ) and three more variable residues $\left(\mathrm{Ile}^{129}, \mathrm{Leu}^{133}, \mathrm{Tyr}^{268}\right.$ ). The residues were individually replaced by alanine to uncover the role of the assessed side chains in their interaction with small-molecule agonists. The results are summarized in Table 1 , where $\mathrm{IC}_{50}$ values are determined from competition binding assay of NDP-MSH against its radioactive analogues, and $\mathrm{EC}_{50}$ values are defined as receptor-mediated accumulation of cAMP induced by corresponding agonists.

The wild type hMC4R binds NDP-MSH and THIQ with $\sim 10$ fold higher affinity $\left(\mathrm{IC}_{50}=1.7\right.$ $\mathrm{nM}$ and $1.2 \mathrm{nM}$, respectively) than $\mathrm{MB} 243\left(\mathrm{IC}_{50}=16 \mathrm{nM}\right)$. The $\mathrm{IC}_{50}$ and $\mathrm{EC}_{50}$ values are similar for each of the three agonists at the wild type receptor. All thirteen mutations alter potencies but do not significantly affect the efficacies of the agonists.

The changes in $\mathrm{IC}_{50}$ and $\mathrm{EC}_{50}$ values for NDP-MSH were also parallel in the majority of tested mutants, with the notable exception of H264A and D126A mutations, which led to significant reduction of NDP-MSH binding affinity such that no specific binding was detected by the filtration method.

The binding affinities and potencies of the small molecule agonists are affected by substitutions of the majority of mutated residues, which are located in TM3, TM6 and TM7 (Table 1). This suggests that these side chains are involved in the direct contact with the small-molecule agonists, although indirect effects cannot be excluded. The relative contributions of the replaced side chains in the ligand-receptor interactions are reflected in the degree of change in the binding affinity in the mutants. Our data indicate that the most important interaction likely involve charged residues ( $\mathrm{Glu}^{100}, \mathrm{Asp}^{122}, \mathrm{Asp}^{126}$, and $\mathrm{His}^{264}$ ), residues from TM6 (Phe ${ }^{261}$ $\mathrm{Leu}^{265}$,) and from TM7 $\left(\mathrm{Leu}^{288}\right)$, as their mutations decrease $\mathrm{IC}_{50}$ and $\mathrm{EC}_{50}$ of both agonists more than 10 fold. These residues are relatively conserved for MCRs 1, 3, 4, and 5 and therefore are not likely to be involved in the specific interactions with MC4R that provide $>100$ fold selectivity of these agonists over MC1R, MC3R, and MC5R $(18,19)$. To reveal the ligandreceptor interactions responsible for the selectivity of these agonists would require additional mutations in other sites of the binding pocket, particularly, in the positions of variable residues 
such as $\mathrm{Leu}^{44}, \mathrm{Val}^{46}, \mathrm{Ile}^{103}, \mathrm{Ile}^{125}, \mathrm{Tyr}^{268}$, which interact with these agonists in our modeled receptor-ligand complexes (see below).

The binding affinities and potencies of small agonists are more sensitive to point mutations than those of peptide agonists: receptor activation by the linear peptide agonist, NDP-MSH, is strongly affected only by D126A and H264A mutations (potency decreased more than 80 fold), and, to a lesser extent, by the E100A mutation. This may be due to more extensive and redundant interactions between the receptor and peptide and perhaps due to peptide flexibility, which allows adjustment inside the modified receptor. In addition, the lower affinity agonist MB243 is much more affected by substitutions of $\operatorname{Trp}^{258}$ and $\mathrm{Phe}^{262}$, than the higher affinity agonist THIQ. These data can guide receptor-ligand docking.

\section{Modeling active conformation of hMC4R}

It is accepted that active and inactive states of GPCR are different and that agonists can preferentially bind to the active conformation. However, an experimental structure has been obtained only for the inactive state of bovine rhodopsin with bound inverse agonist, 11cisretinal $(23,24)$. Recently we have developed an active state model for the $\mu$-opioid receptor, based on the crystal structure of rhodopsin and a set of experimental constraints (disulfides, metal binding clusters, etc.) that facilitate activation (31). This model was applied here as a template for modeling of hMC4R (see Experimental Procedures). After calculations, the active state models of hMC4R and $\mu$-opioid receptor superimpose well in the TM domain (r.m.s.d. $1.6 \AA$ for 205 C $\alpha$-atoms).

A comparison of models for the active and inactive states of hMC4R reveals the structural changes that accompany activation. Overall r.m.s.d. of these models is $2.4 \AA$ for all common $282 \mathrm{C}^{\alpha}$ atoms, but decreases to $1.8 \AA$ (for $166 \mathrm{C} \alpha$ atoms) after excluding TM6 and interhelical loops, which undergo movement during activation. TM6 shifts outward and rotates counterclockwise (viewed from the extracellular side) during activation, moving its intracellular end away from TM3 and toward TM5. As a result of this and other changes, the receptor structure tightens near its extracellular surface, but opens up at the cytoplasmic side, providing a cavity for binding of the Gas subunit. In the active state, several side chains

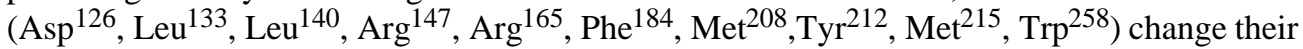
orientation, which affects the geometry of the binding pocket and alters interhelical H-bonds, especially between residues from TMs $3,6,7$, exactly as observed for the $\mu$-receptor (31). The most significant changes can be described as follows. First, the concerted movements of $\operatorname{Trp}^{258}$ ( $\varkappa 2$ rotation from $\sim 90^{\circ}$ to $\sim 20^{\circ}$ ), Asp ${ }^{126}$, and Leu ${ }^{133}\left(\varkappa 1\right.$ rotation from $\sim 180^{\circ}$ to $\sim-60^{\circ}$ ) residues affect the shape of the ligand binding pocket at its bottom, making it more suitable for agonist. Second, the counterclockwise rotation of TM6 brings His ${ }^{264}$ into the binding pocket, shifts $\mathrm{Phe}^{261}{ }^{2} \mathrm{Leu}^{265}$, and $\mathrm{Tyr}^{268}$, and moves $\mathrm{Phe}^{262}$ toward the lipid. This explains the larger effect of mutations involving $\mathrm{His}^{264}, \mathrm{Phe}^{261}$, $\mathrm{Leu}^{265}$, and $\mathrm{Tyr}^{288}$ residues and the relatively minor effect of F262A substitution on agonist binding affinities and potencies (Table 1). Third, the rotating Arg ${ }^{147}$ residue (from the conserved DRY motif in TM3) breaks an Hbond with the adjacent Asp ${ }^{146}$, but forms new H-bonds with $\mathrm{Tyr}^{212}$ (TM5) and $\mathrm{Tyr}^{302}$ (TM7), while the released Asp ${ }^{146}$ residue forms a new H-bond with $\mathrm{Arg}^{165}$ from IL2. This affects the shape of the intracellular binding cavity for Gas.

A distinct feature of the melanocortin receptors is the deletion of the $\beta$-hairpin from EL2, together with a highly conserved disulfide bond connecting this $\beta$-hairpin to TM3, features generally found in the rhodopsin family of GPCRs. Instead, the structure can be stabilized by two additional disulfide bridges, connecting EL3 with the N-terminus $\left(\mathrm{Cys}^{40}{ }_{-} \mathrm{Cys}^{279}\right.$ ), or EL3 with TM6 (Cys ${ }^{271}{ }_{-} \mathrm{Cys}^{277}$ ) (33). The deletion of the $\beta$-hairpin from EL2 creates a large, elongated ligand binding cavity containing several acidic residues. The walls of this cavity are formed by $\mathrm{Leu}^{44}, \mathrm{Val}^{46}$ (N-terminus), $\mathrm{Phe}^{51}$ (TM1), Glu ${ }^{100}$, Ile ${ }^{103}$, and $\mathrm{Ile}^{104}$ (TM2), 
Asp ${ }^{122}, \mathrm{Ile}^{125}, \mathrm{Asp}^{126}, \mathrm{Ile}^{129}, \mathrm{Cys}^{130}$, and Leu ${ }^{133}$ (TM3), Ser ${ }^{175}$ and Phe ${ }^{184}$ (TM4), Val ${ }^{193}$, Cys ${ }^{196}$ and Met ${ }^{200}$ (TM5), Trp ${ }^{258}, \mathrm{Phe}^{261}, \mathrm{His}^{264}, \mathrm{Leu}^{265}$, and Tyr ${ }^{268}$ (TM6), $\mathrm{Phe}^{284}, \mathrm{Leu}^{288}$, and $\mathrm{Met}^{292}$ (TM7), Ser ${ }^{188}$ and Ser ${ }^{190}$ (EL2), and $\mathrm{Met}^{281}$ (EL3) residues, many of which were probed in our mutagenesis experiments. This cavity can be filled by the $\mathrm{N}$-terminal region of the receptor or by natural peptide agonists $(\alpha, \beta, \gamma-\mathrm{MSH})$.

\section{Docking of small-molecule agonists into active state model of hMC4R}

Both peptidomimetic agonists have a common tripeptide scaffold, with 4-Cl or 4-F derivatives

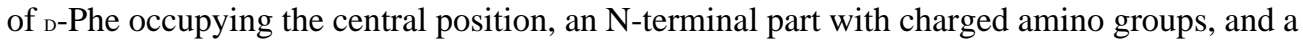
C-terminal portion formed by 4,4-disubstituted piperidines. Both ligands have limited flexibility, with rotations allowed around several single bonds (Figure 1). One of the agonists, THIQ, has been extensively studied by crystallography, NMR in solution, theoretical calculations, and analysis of structure-activity relationships of its analogues $(18,48)$. THIQ has two nearly identical crystal structures, with an extended polypeptide backbone and piperidine and cyclohexane groups in the chair conformation (48). The crystal structure resembles the tentative biologically active conformation (18). In these conformations the 4-chlorophenyl group and piperidine ring are close and interact with each other, while the aromatic ring of $\mathrm{D}^{-}$ Tic is oriented in the opposite direction, and the 1,2,4-triazol ring is highly exposed to the environment. After local energy minimization, one of the crystal structures has the lowest energy, while the other has $\Delta \mathrm{E}=0.8 \mathrm{kcal} / \mathrm{mol}$. Our theoretical conformational analysis of THIQ identified 12 clusters of conformers with $\Delta \mathrm{E}<3 \mathrm{kcal} / \mathrm{mol}$, all of which were used for docking.

The docking of THIQ was guided by placement of its key pharmacophore elements of the ligand in contact with receptor residues that were found to be most important for binding affinities and potency, i.e. Glu ${ }^{100}, \mathrm{Asp}^{122}$, Asp ${ }^{126}, \mathrm{Phe}^{261}, \mathrm{Leu}^{265}, \mathrm{His}^{264}$, and Leu ${ }^{288}$ (Table 1). Two "anchor" pharmacophore groups were the aromatic halogen-substituted ring of the central $\mathrm{D}$-Phe residue and the positively charged amine nitrogen (Figure 1). Both groups are present in either natural melanocortin peptides or synthetic agonists $(18,19,49)$. In the model of the complex, the central aromatic ring of ${ }_{\text {D-Phe }}(4-\mathrm{Cl})$ contacts with $\mathrm{Phe}^{261}$ and $\mathrm{Leu}^{288}$, the amine group was placed near Glu ${ }^{100}, \mathrm{Asp}^{122}$, and $\mathrm{Asp}^{126}$ and the 1,2,4-triazole ring of the peptidomimetic interacts with $\mathrm{His}^{264}$. The ${ }_{\mathrm{D}} \mathrm{Phe}(4-\mathrm{Cl})$ aromatic ring was arranged between TM3 and TM6, in a position and orientation that is similar to that of the tyramine segment of opioid ligands in the $\mu$-opioid receptor (31). The elongated binding cavity can accept only the extended conformations of the ligand with $\varkappa^{1}$ of ${ }_{\mathrm{D}}-\mathrm{Phe} \sim 180^{\circ}$. Conformers of THIQ that are more compact or have $\pm 60^{\circ} \varkappa 1$ conformers of ${ }^{\circ}$-Phe can not be docked without steric overlap with the receptor.

A number of extended low-energy conformers of THIQ could be fitted to the cavity, including the crystallographic structures. These conformers had slightly different orientations of $\mathrm{D}$-Tic and the 1,2,4-triazole ring. The best fitting conformation of THIQ $\left(\psi 1=59, \varphi 2=79^{\circ}, \psi 2=\right.$ $-141^{\circ}, x 1=180^{\circ}, \omega 2=180^{\circ}, \varkappa 2=-70^{\circ}, \varkappa 3=-71^{\circ}$, and $\varkappa 4=64^{\circ}$ ) was not of lowest energy in isolation $(\Delta \mathrm{E}=1.1 \mathrm{kcal} / \mathrm{mol})$. However, it formed energetically favorable $\mathrm{H}$-bonds with the receptor $\left(\mathrm{N}^{+}\right.$to $\mathrm{Asp}^{122}$ and $\mathrm{Asp}^{126}$ and 1,2,4-triazol to His ${ }^{264}$ ), unlike the crystal structures. It is quite possible that the ligand retains some residual flexibility around $\psi 1, \varphi 2, x 2, x 3$ and $\varkappa 4$ dihedral angles when bound to the receptor. Such flexibility helps to explain high binding affinity and potency of either ${ }_{\mathrm{L}}$-Tic or $\mathrm{D}_{\mathrm{D}}$ Tic in THIQ analogue (18).

Receptor-bound THIQ has multiple favorable interactions with hMC4R residues (Figure 3). For example, the side-chain of the central o-Phe (4-Cl) residue occupies the bottom of the binding cavity and interact with $\mathrm{Ile}^{129}$, $\mathrm{Leu}^{133}, \mathrm{Trp}^{258}, \mathrm{Phe}^{261}$ and $\mathrm{Leu}^{288}$ residues, most of which are important for binding and activation by THIQ (Table 1). The ${ }_{\mathrm{p}}$-Tic of THIQ is situated between $\mathrm{Leu}^{44}, \mathrm{Val}^{46}$, preceding TM1, and residues from TM2 (Glu ${ }^{100}, \mathrm{Ile}^{103}$, $\left.\mathrm{Ile}^{104}\right)$, TM3 ( $\left.\mathrm{Asp}^{122}, \mathrm{Ile}^{125}, \mathrm{Asp}^{126}\right)$ and TM7 $\left(\mathrm{Asn}^{285}\right)$. The charged amino group of $\mathrm{p}$-Tic 
forms ionic interactions with several acidic residues from TMs 2 and 3 including the most functionally important Asp ${ }^{126}$, with which it also forms an H-bond. Moreover, Asp ${ }^{126}$ forms an $\mathrm{H}$-bond with the backbone amide group of $\mathrm{D}_{\mathrm{D}} \mathrm{Phe}$, which restrains the position of the ligand inside the binding pocket. The triazole part of THIQ occupies a spot between TMs 3-7. Its piperidine ring forms contacts with $\mathrm{Phe}^{184}$ (TM4) and $\mathrm{Phe}^{284}$ (TM7), the cyclohexyl ring is situated between $\mathrm{Val}^{193}{ }^{19}$ Cys $^{196}$ (TM5) and Leu ${ }^{265}$ (TM6), and the polar triazole group interacts with Leu ${ }^{265}$, His ${ }^{264}$ and $\mathrm{Tyr}^{268}$ (TM6).

A similar analysis was carried out for the THIQ analogue with L-stereoisomer of the central Phe residue. The extended low-energy conformation of $\mathrm{L}$-Phe-THIQ does not fit the binding pocket due to changes in backbone angles $\left(\varphi 2=-78^{\circ}, \psi 2=142^{\circ}\right)$, resulting in the reorientation of the first peptide bond, a broken receptor-ligand $\mathrm{H}$-bond, and steric clashes between the shifted ligand and TM6 ( $\mathrm{Tyr}^{268}$ ). This may explain the low affinity and potency observed for

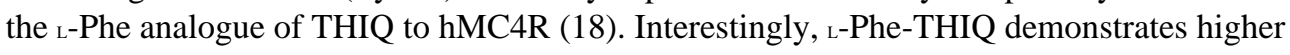
affinity toward hMC3R and hMC5R, but does not exhibit agonist properties in these receptors (18). The increased binding affinity of L-Phe-THIQ to other MCRs may be related to the substitution of $\mathrm{Tyr}^{268}$ (TM6) in hMC4R by Ile in MC3R or Met in MC5R. At the same time, the reorientation of the first peptide group in ${ }_{\mathrm{L}} \mathrm{Phe}-\mathrm{THIQ}$ breaks the H-bond between the functionally important $\mathrm{Asp}^{126}$ and $\mathrm{NH}$ of ${ }_{\mathrm{L}}$-Phe and forces the rotation of $\mathrm{Asp}^{126}$ to a position appropriate for the inactive receptor state $\left(\varkappa 1 \sim 180^{\circ}\right)$. This $\mathrm{Asp}^{126}$ reorientation may be responsible for the loss of agonistic activity of this ligand. Furthermore, substitution of ${ }_{D}-P h e$ by the larger aromatic side chain of ${ }_{\mathrm{D}}-\mathrm{Nal}\left(2^{\prime}\right)$ also results in the loss of agonism (18). In our model of the active state of hMC4R, ${ }^{-N a l}\left(2^{\prime}\right)$ exhibits some hindrances with the indole ring of $\operatorname{Trp}^{258}$ from TM6. However, these hindrances disappear in the inactive conformation of hMC4R, where the indole ring of $\operatorname{Trp}^{258}$ changes its orientation, in coordination with rotation of Leu ${ }^{133}$ from TM3. This is consistent with the observed antagonistic properties of D-Nal(2')THIQ (18).

The lowest-energy conformer of MB243 was structurally more compact than that of THIQ, and does not fit the binding pocket. Only an extended conformation $(\Delta \mathrm{E}=1.85 \mathrm{kcal} / \mathrm{mol})$ with $\psi 1=158^{\circ}, \varphi 2=76^{\circ}, \psi 2=-135^{\circ}, x 1=179^{\circ}, \omega 2=178^{\circ}, x 2=-175^{\circ} x 3=54^{\circ}$, which resembles the bound conformation of THIQ, could be docked into the model of hMC4R (Figure 4). The higher energy of the receptor-bound conformation of MB243 is consistent with 10-fold lower binding affinity, relative to THIQ. Both small agonists interact with the same residues of receptor, with only relatively minor differences, such as the appearance of an H-bond between methylated amine of piperazine of MB243 and Glu ${ }^{100}$ in addition to the ionic interaction betwen second $\mathrm{N}^{+}$of piperazine and $\mathrm{Asp}^{122}$, $\mathrm{Asp}^{126}$, and formation of H-bond between tertbutylamide group of MB243 and His ${ }^{264}$, while THIQ forms only one $\mathrm{H}$-bond between its $\mathrm{N}^{+}$ and $\mathrm{Asp}^{126}$ and interacts with $\mathrm{His}^{264}$ by its 1,2,4-triazole group. These differences may cause the more pronounced effects of E100A and H264A mutations on the potency of MB243, relative to THIQ (Table 1). MB243 in the receptor retains some rotational flexibility of $\psi 1$, $\varphi 2$, and $\varkappa 2$ dihedral angles. In particular, the piperazine can be oriented in the receptor with its N-methyl group facing either the middle or the extracellular part of the pocket. Therefore, different substituents at the $\mathrm{N}$-methyl group of piperazine ring can be adopted in the binding pocket with rather similar affinity (19). The space around N-methyl-piperazine is reduced in other MCR subtypes, due to replacements of $\mathrm{Leu}^{44}, \mathrm{Val}^{46}, \mathrm{Ile}^{103}$ and $\mathrm{Ile}^{125}$ residues by Val, Ile, Met and Phe, respectively in hMC3R, or by Met, Ile, Thr, Phe, respectively in hMC5R. This may explain the lower affinity and potency of MB243 toward these receptors (19). On the other hand, the antagonistic properties of the ${ }_{\mathrm{L}}$-Phe analogue of MB243 toward all three MCRs (19) could be explained by the broken H-bond between the important Asp ${ }^{126}$ and the first peptide bond of ligand, and the forced reorientation of $\mathrm{Asp}^{126}$, similar to the situation described above for the ${ }_{\mathrm{L}}-\mathrm{Phe}$ analogue of THIQ. 


\section{Distance geometry modeling of receptor-peptide complexes}

Finally, we calculated the complex of hMC4R with peptide agonist NDP-MSH. The initial model of the complex was generated assuming that "message" residues of the peptide (His ${ }^{6}$ D-Phe $-\mathrm{Arg}^{8}-\operatorname{Trp}^{9}$ ) would mimic the corresponding pharmacophore elements of THIQ: His ${ }^{6}$ of the peptide was positioned similar to $\mathrm{D}_{\text {-Tic }}$ of THIQ; guanidium group of $\mathrm{Arg}^{8}$ formed ionic interactions with the functionally important $\mathrm{Asp}^{126}$ similar to the positively charged amine of D-Tic; ${ }^{\mathrm{D}}-\mathrm{Phe}^{7}$ was overlapped with $\mathrm{D}-\mathrm{Phe}(4-\mathrm{Cl})$ of THIQ, and $\operatorname{Trp}^{8}$ mimicked the C-terminal group of THIQ. The subsequent distance geometry refinement of the complex (see Experimental Procedures) helped to maximize the set of peptide-receptor H-bonds and adjust geometry of the peptide and conformers of surrounding receptor side-chains. During the calculations, we also used constraints between residues 4-10, and 5-10, which were introduced to mimic disulfide and lactam bridges from cyclic peptide agonists, $\left[\mathrm{Cys}^{4}-\mathrm{Cys}^{10}{ }^{10}-\alpha \mathrm{MSH}\right.$ (43) and MT-II (44), respectively.

This computational approach defined the structural details of the receptor-bound conformation of both $\alpha-\mathrm{MSH}$ and NDP-MSH (Table 2) and confirmed their proposed arrangement inside the receptor (Figure 5). The backbone conformation and $x 1$ angles in fragment 3-12 of both peptides and their position inside the receptor were determined unequivocally (r.m.s.d. $1.2 \AA$ for $\mathrm{C} \alpha$-atoms 3-12 of peptides in 10 superposed receptor models). Both peptide ligands demonstrate a $\beta$-hairpin-like structure with a reverse turn spanning $\mathrm{His}^{6}$ and $\mathrm{L}^{-}$or $_{\mathrm{D}}-\mathrm{Phe}^{7}$. In this conformation the phenyl ring of $\mathrm{L}_{\mathrm{L}}$ or $\mathrm{D}_{\mathrm{D}} \mathrm{Phe}^{7}$ interacts with the indole ring of $\operatorname{Trp}^{9}$, forming a hydrophobic patch, while charged $\mathrm{Glu}^{5}$ and $\mathrm{Arg}^{8}$ are located on different sides of the $\beta$ hairpin.

In the binding pocket of hMC4R eithera-MSH or NDP-MSH forms at least $7 \mathrm{H}$-bonds with receptor residues: $\mathrm{His}^{264}$ (TM6) with the carboxylate group of Asp ${ }^{5}$ and carbonyl of Trp9; Glu ${ }^{100}$ (TM2) with the imidazole group of $\mathrm{His}^{6}$; Asp $^{122}$ and Asp ${ }^{126}$ with the guanidium group of $\operatorname{Arg}^{8}, \mathrm{Asp}^{126}$ (TM3) with the amide group of ${ }_{\mathrm{L}, \mathrm{D}}-\mathrm{Phe}^{7}$; $\mathrm{Asp}^{189}$ (EL2) with the amine group of Lys ${ }^{11}$. These $\mathrm{H}$-bonds were included in calculations of receptor-peptide complexes. Several additional H-bonds were also found in many calculated structures: $\mathrm{Asp}^{37}$ (N-terminus) with $\mathrm{Ser}^{1}$; $\mathrm{Thr}^{118}$ (EL1) with $\mathrm{Tyr}^{2}$; Glu ${ }^{42}$ (N-terminus) with $\mathrm{Ser}^{3}, \mathrm{Thr}^{118}$ (EL1) with $\mathrm{Arg}^{8}$, Tyr268 (TM6) with carbonyl of Gly ${ }^{10}$. His $^{6}$ of the peptide ligands is buried between polar side chains of $\mathrm{Glu}^{100}$, Asp ${ }^{122}$ and $\mathrm{Asn}^{285}$ and can form alternative H-bonds with these residues, while $\mathrm{Arg}^{8}$ is water exposed and can form ionic interactions with both Asp ${ }^{122}$ and $\mathrm{Asp}^{126}$. The phenyl ring of ${ }_{\mathrm{L}, \mathrm{D}}-\mathrm{Phe}^{7}$ of peptides occupies the bottom of the cavity between $\mathrm{Ile}^{129}, \mathrm{Cys}^{130}{ }^{13} \mathrm{Leu}^{133}$, $\mathrm{Trp}^{258}, \mathrm{Phe}^{261}$ and Leu ${ }^{288}$, similar to $\mathrm{D}-\mathrm{Phe}(4-\mathrm{Cl})$ of THIQ. The slightly different orientation for ${ }_{\mathrm{D}}-\mathrm{Phe}^{7}$ relative to its $\mathrm{L}$-enatiomer inside the pocket may be responsible for the greater potency and prolonged activity of NDP-MSH, relative to $\alpha-\mathrm{MSH}(36,50)$ and for the larger effect of W258A mutation on the binding affinity and potency of $\alpha$-MSH relative to NDP-MSH (37). $\mathrm{Trp}^{9}$ of both peptides interacts with Leu ${ }^{265}$, His ${ }^{264}$, and $\mathrm{Phe}^{284}$ of the receptor, similar to the C-terminal 4,4'-substituted piperidine of THIQ. Such an arrangement of NDP-MSH inside the binding pocket explains the substantial effects of E100A, D126A, H264A, and L265A mutations on the potency and affinity of this peptide (Table 1).

\section{Discussion}

In this study we have identified residues of hMC4R that may interact with two small molecule agonists and peptide agonists by examining the effects of thirteen mutations on ligand binding and activation of the receptor. This allowed the development of putative 3D models of complexes of hMC4R with either THIQ or MB243, based on current data, SAR of smallmolecule agonists $(18,19)$, and our previous modeling studies of inactive (antagonist-bound) and active (agonist-bound) states of different GPCRs $(31,33)$. Subsequently, the models of hMC4R with two linear peptide agonists, NDP-MSH and $\alpha-\mathrm{MSH}$, were calculated by distance 
geometry assuming that the most functionally significant side-chains of the peptide (His ${ }^{6}$, ${ }^{-}$ $\mathrm{Phe}^{7}, \mathrm{Arg}^{8}$ and $\operatorname{Trp}^{9}$ ) are spatially overlapped with the corresponding pharmacophore groups of THIQ. The resulting models with peptide agonists were different in atomic details from those in earlier studies (16,47,51-53). The proposed peptide-receptor complexes were consistent with the notion that the core residues of flexible peptides reproduced the receptorbound structure of the more conformationally rigid small molecule agonists. The peptide flexibility was also restrained during calculation by packing interactions and $\mathrm{H}$-bonds with the receptor, and by several intramolecular cross-linking constraints taken from related bioactive cyclic peptides.

The most important pharmacophore element of all melanocortin agonists is an aromatic ring of the central $\mathrm{D}$-Phe residue $(18,19,49,54)$. It is inserted at the bottom of the binding cavity in close proximity to the conserved $\operatorname{Trp}^{258}$ residue that triggers activation of GPCRs $(31,55)$. This region is occupied by the polyene chain of retinal in rhodopsin (24) or by the tyramine portion of opioid ligands (31). Some interesting details of receptor-ligand interactions can be observed upon superimposition of hMC4R models in complex with the antagonist AGRP (inactive state), with the peptide agonist NDP-MSH, and with small-molecule agonist THIQ (Figure 6). Three key pharmacophore groups of these ligands are similar: (a) phenyl rings of Phe ${ }^{112}$ of AGRP, ${ }_{\text {D-Phe }}{ }^{7}$ of NDP-MSH, and ${ }_{\mathrm{D}}-\mathrm{Phe}(4-\mathrm{Cl})$ of THIQ; (b) side chain of Arg ${ }^{111}$ of AGRP, and charged groups of $\mathrm{His}^{6}$ and $\mathrm{Arg}^{8}$ in NDP-MSH, and $\mathrm{N}^{+}$group of ${ }_{\mathrm{D}}$-Tic in THIQ; and (c) phenyl ring of Phe ${ }^{113}$ of AGRP, indole ring of $\operatorname{Trp}^{9}$ of NDP-MSH, and cyclohexane ring of THIQ. The corresponding groups are not completely overlapped, but they occupy the same areas of space and interact primarily with the same receptor residues.

The models of the receptor-agonist complexes help to interpret the observed effects of hMC4R mutations on binding affinity and potency of agonists (Table 1). Some residues whose mutations have been shown to affect activation may be in direct contact with ligands. For example, in the proposed models of hMC4R with small molecule agonists Glu ${ }^{100}$, Asp ${ }^{122}$, and Asp ${ }^{126}$ residues form $\mathrm{H}$-bonds and ionic interactions with the positively charged $\mathrm{N}^{+}$of THIQ (D-Tic) or the piperazine ring of MB243. In the proposed models of hMC4R with peptide agonists, His ${ }^{6}$ of both peptide ligands is completely buried in the pocket and can form an $\mathrm{H}$ bond either to $\mathrm{Glu}^{100}$ or to $\mathrm{Asn}^{285}$, while their $\mathrm{Arg}^{8}$ residue is more exposed to water and makes ionic interactions and $\mathrm{H}$-bonds with $\mathrm{Asp}^{122}$ and $\mathrm{Asp}^{126}$. The reduced ionic interactions of $\mathrm{Arg}^{8}$ in water and the flexibility of His ${ }^{6}$ can explain the smaller effect of E100A and D122A replacements on the potency of NDP-MSH, relative to their effect on potency of small agonists (Table 1). Among all acidic residues of MCRs, Asp $^{126}$ appears to be the most important for potency of all agonists (>100 fold increase of $\mathrm{EC}_{50}$ in D126A mutant). The essential role of Asp $^{126}$ may be due to its H-bond with the backbone $\mathrm{NH}$ group of central $\mathrm{D}^{-}$or $_{\mathrm{L}}$-Phe residues in all agonists (this H-bond forces reorientation of $\mathrm{Asp}^{126}$ in the active state). His ${ }^{264}$ may be more important for NDP-MSH binding because it forms two $\mathrm{H}$-bonds with the peptide (with $\mathrm{COO}^{-}$of $\mathrm{Glu}^{5}$ and backbone $\mathrm{C}=\mathrm{O}$ of $\mathrm{Trp}^{9}$ ), but only one H-bond with either THIQ (with 1,2,4triazole) or MB243 ( $\mathrm{C}=\mathrm{O}$ group). L265A mutation demonstrates a large effect only on the binding affinity and the potency of small-molecule agonists (Table 1) probably because the aliphatic side-chain of Leu ${ }^{265}$ is more tightly packed with the cyclohexane ring of the peptidomimetics than with the corresponding planar ring of $\operatorname{Trp}^{9}$ of the peptide. It can not be excluded, however, that D126A and H264A mutations may also impair plasma membrane targeting and/or assembly, as radiolabel binding and functional activation is dramatically reduced for these mutants.

Our models are consistent with receptor-bound conformations of agonists that have been proposed previously $(18,48,56-59)$. The best-fitting conformation of small agonist, THIQ was similar to the crystal structure of this molecule (see Results). It has also been proposed that aromatic rings of ${ }_{\mathrm{D}, \mathrm{L}}-\mathrm{Phe}^{7}$ and $\mathrm{Trp}^{9}$ residues of $\mathrm{MSH}$ peptide form a continuous cluster on one 


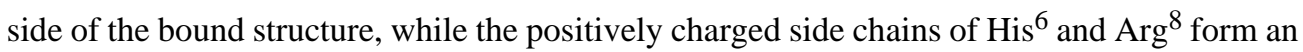
opposite 'hydrophilic surface' $(56,57)$. Indeed, such aromatic and charged clusters are present in our models. These two clusters interact with aromatic residues from TMs 3-7 and negatively charged residues from TMH 2-3, respectively. Furthermore, the bound conformation of NDPMSH peptide has a type II $\beta$-turn formed by $\mathrm{His}^{6}$ and ${ }_{\mathrm{L}, \mathrm{D}}-\mathrm{Phe}^{7}$ residues, as has been suggested previously based on NMR and computational studies of these peptides in aqueous solution $(58,59)$. However this $\beta$-turn is distorted in $\alpha$-MSH, where backbone angles of the central $\mathrm{L}, \mathrm{D}-$ $\mathrm{Phe}^{7}$ and $\mathrm{Arg}^{8}$ residues are different (Table 2). The $\beta$-hairpin-like structure of the peptides was obtained because the $\mathrm{C}^{\beta}$ atoms of residues 4-10 and 5-10 were kept in close proximity to each other ( $4.5 \AA$ and $7.5 \AA$, respectively) during distance geometry calculations, thus allowing the cyclization through a disulfide bond in $\left[\mathrm{Cys}^{4}, \mathrm{Cys}^{10}\right]-\alpha-\mathrm{MSH}(43)$ or a lactam bridge between $\mathrm{Asp}^{5}$ and Lys ${ }^{10}$ in MT-II (44). Further, in the calculated structures of $\alpha$-MSH and NDP-MSH the $C^{\beta} \ldots C^{\beta}$ distances between residues 3-11 ( 8.5 $\left.\AA\right), 4-11(\sim 8.0 \AA)$, 5-8 $(\sim 7.5 \AA)$ and 5-11 $(\sim 12 \AA)$, are compatible with formation of the corresponding disulfide or lactam bridges in other cyclic peptide agonists, such as Ac-cyclo[Cys3,Nle10, D-Nal7,Cys11] $\alpha-M S H(3-11)$ $\mathrm{NH}_{2}$, Ac-cyclo[Cys4,o-Na17, Cys11] $\alpha-\mathrm{MSH}(4-11) \mathrm{NH}(60,61), \mathrm{Ac}^{-N_{l}{ }^{4}} 2$-cyclo[o-Orn $\left.{ }^{5}, \mathrm{Glu}^{8}\right]$ $\alpha-\mathrm{MSH}(4-11) \mathrm{NH}(62)$ and Ac-Nle $-\mathrm{cyclo}\left[\mathrm{Asp}^{5} 2, \mathrm{p}-\mathrm{Phe}^{7}, \mathrm{Aib}^{10}, \mathrm{Lys}^{11}\right] \alpha-\mathrm{MSH}(4-11) \mathrm{NH}_{2}(57)$, respectively.

During our calculations of receptor-peptide complexes the side-chains of $\mathrm{His}^{6}$ and (L,D)$\mathrm{Phe}^{7}$ residues of peptides were restrained in gauche- $\left(x 1 \sim-60^{\circ}\right)$ and trans $\left(\varkappa 1 \sim 180^{\circ}\right)$ conformations, respectively, to mimic orientations of the aromatic rings of $\mathrm{D}_{\mathrm{D}} \mathrm{Tic}^{1}$ and $p$-Cl-D$\mathrm{Phe}^{2}\left(\varkappa 1 \sim 180^{\circ}\right)$ in the receptor-bound conformations of THIQ. Such rotamers are welladopted inside the binding pocket of hMC4R. This orientation of the imidazole ring of $\mathrm{His}^{6}$ is consistent with the position of the aromatic ring of the $x$-constrained (2S,3R)3-phenyl-Pro ${ }^{6}$ residue of the MT-II analogue, which retains bioactivity (59). On the other hand, the proposed trans rotamer of ${ }_{\mathrm{D}}-\mathrm{Phe}^{7}$ places the aromatic ring in a different location than the aromatic ring of the (2R, 3S)Phe-Pro ${ }^{7}$-MT-II analogue, which is completely inactive (59). These data represent additional evidence supporting the proposed side chain orientations of $\mathrm{His}^{6}$ and $\mathrm{D}$ $\mathrm{Phe}^{7}$ inside the receptor binding pocket.

The proposed models help to explain SAR of the small agonists, for example the importance of the ${ }_{\mathrm{D}}$-stereoisomer of $\mathrm{Ph}^{2}$ for binding and bioactivity of THIQ and MB243, the antagonistic properties of its ${ }^{-}-\mathrm{Nal}\left(2^{\prime}\right)$-analogue, and the high potency of a THIQ analogue with a $\mathrm{L}$-Tic residue (18), as was described in Results. Furthermore, it has recently been proposed that the pharmacophore core ' $\mathrm{His}^{6}{ }_{-\mathrm{D}}-\mathrm{Phe}^{7}-\mathrm{Arg}^{8}-\mathrm{Trp}^{9}$ ' of MT-II is arranged in the binding pocket similar to the important structural elements of THIQ, based on the comparison of SARs of THIQ and MT-II (18). The results of our modeling support this conclusion.

The models are also consistent with SAR of the peptide ligands $(47,49,63,64)$. In the models the positively charged $\mathrm{Arg}^{8}$ of peptides is located close to the extracellular surface of the receptor and it participates in the H-bond network with acidic residues from TM3 (Asp ${ }^{122}$, $\mathrm{Asp}^{126}$ ). The likely presence of water around $\mathrm{Arg}^{8}$ should decrease the role of ionic interactions with this residue. Indeed, the $\mathrm{Arg}^{8} \rightarrow \mathrm{Glu}^{8}$ substitution in MT-II is tolerated, resulting only in $\sim 40$ fold loss of potency compared to the parent peptide (65). The negatively charged Glu ${ }^{5}$ of the peptide ligands is located on the opposite side of its $\beta$-hairpin-like structure, forming $\mathrm{H}$ bond and ionic interactions with basic His ${ }^{264}$ in TM6. Interestingly, this acidic residue is shifted from position 5 to position 10 in $\gamma-\mathrm{MSH}$, which is selective for MC3R. As a result, $\mathrm{Asp}^{10}$ of $\gamma \mathrm{MSH}$ can form an ionic interaction with Lys ${ }^{223}$ (TM5) of hMC3R that in hMC4R is substituted by $\mathrm{Ser}^{191}$. This is consistent with the observed importance of $\mathrm{Asp}^{10}$ for MC3-selectivity (66). Further, the $\mathrm{Phe}^{7}$ residue is most essential for binding and activity of MCR ligands $(49,54)$. Its aromatic ring is situated on the bottom of the receptor pocket and surrounded by Asp ${ }^{126}$, $\mathrm{Leu}^{133}$ and $\operatorname{Trp}^{258}$ side-chains that rotate during activation in our model. The bulkier ${ }_{\mathrm{D}} \mathrm{Nal}$ 
$\left(2^{\prime}\right)^{7}$ in peptide analogues overlaps with Leu ${ }^{133}$ in the active receptor conformation, but it can be accommodated easily in the inactive receptor state, where Leu ${ }^{133}$ and $\operatorname{Trp}^{258}$ change orientation. This is consistent with the functional antagonism of ${ }_{\mathrm{D}} \mathrm{Nal}\left(2^{\prime}\right)^{7}$-containing peptides in MC4R, but not in MC1R, where Leu ${ }^{133}$ is substituted by Met $(54,63)$. Indeed L133M mutation in hMC4R converts $\mathrm{D}-\mathrm{Nal}\left(2^{\prime}\right)^{7}$-containing SHU9119 into an agonist (67). Another residue essential for high affinity of the peptide ligands is $\operatorname{Trp}^{9}(49)$. It is located in a hydrophobic-aromatic pocket, enclosed by Phe ${ }^{184}$, Cys ${ }^{196}, \mathrm{Met}^{200}, \mathrm{Phe}^{261}, \mathrm{His}^{264}$, $\mathrm{Leu}^{265}$, $\mathrm{Phe}^{284}$. This large pocket is suitable for different aromatic substitutions, but not for small or polar side chains. Indeed, potent agonists are those with $\operatorname{Trp}^{9},{ }_{\mathrm{L}, \mathrm{D}}-\mathrm{Nal}\left(2^{\prime}\right)^{9}, \mathrm{~L}_{\mathrm{L}} \mathrm{Nal}\left(1^{\prime}\right)^{9}$ or 3benzothienylalanine, while ligands with $\mathrm{Ala}^{9}$, $\mathrm{His}^{6}$, and $\mathrm{Lys}^{9}$ lose their activity $(65,68)$. In contrast, the region around $\mathrm{His}^{6}$ is formed by polar and aliphatic residues $\left(\mathrm{Leu}^{44}, \mathrm{Val}^{46}\right.$, $\mathrm{Glu}^{100}, \mathrm{Ile}^{103}, \mathrm{Asp}^{122}, \mathrm{Ile}^{125}, \mathrm{Asp}^{126}, \mathrm{Asn}^{285}$ ) and, therefore, can adopt both polar and aromatic side chains $(64,65,68)$.

Our modeling of hMC4R does not include the N-terminal fragment, which can be deleted without loss of receptor activity (69). However, it has been recently suggested that the Nterminal domain could function as a tethered intramolecular ligand, which provides intrinsic constitutive activity of hMC4R responsible for the tonic satiety signal (70). Indeed, the $\mathrm{N}$ terminus (residues ${ }^{15}$ LWNRSSYRLHSNA ${ }^{27}$ of hMC4R) can be positioned similar to the natural agonist, $\alpha$-MSH (residues ${ }^{1}$ SYSMEHFRWGKPV ${ }^{13}$ ) in our model. In this case, their central tetrapeptide fragments (indicated in bold) structurally match each other, and the functionally important $\mathrm{Arg}^{18}$ of the $\mathrm{N}$-terminus, whose mutations are associated with obesity (70), interacts with the functionally important acidic residues from TM3 of hMC4R (Figure 7).

In summary, we propose 3D models of complexes of hMC4R with either small molecule agonists (THIQ, MB243), or linear peptides ( $\alpha$-MDH, NDP-MSH), based on our mutagenesis data. The models are consistent with published structure-activity and conformational studies of the ligands. They can be applied in future studies of residues responsible for high selectivity of small-molecule agonists to MC4R using mutations of receptor type-specific ligand contact residues proposed by the model (for example, $\mathrm{Leu}^{44}, \mathrm{Val}^{46}$, $\mathrm{Ile}^{103}, \mathrm{Ile}^{125}$ ) to extend the results of this study. The models can also be used for computational analysis of binding of many agonists that were not considered here (71-75)), for finding potential metal binding sites in MCRs (42,76,77), and for rational drug design.

The atomic coordinates of the described models are publicly available at http://mosberglab.phar.umich.edu/resources/index.php.

\section{Supplementary Material}

Refer to Web version on PubMed Central for supplementary material.

\section{Acknowledgment}

The authors are grateful to Dr. Jarl E.S. Wikberg for the coordinates of the crystal structure of THIQ, described in a recent paper (48).

\section{Abbreviations}

GPCR, G protein-coupled receptor

MCR, melanocortin receptor

$\mathrm{TM}$, transmembrane helix

EL, extracellular loop

IL, intracellular loop 
SAR, structure activity relationship

$\alpha$-MSH, $\alpha$-melanocyte stimulating hormone or Ac-Ser ${ }^{1}-\mathrm{Tyr}^{2}-\mathrm{Ser}^{3}-\mathrm{Met}^{4}-\mathrm{Glu}^{5}-\mathrm{His}^{6}{ }^{6} \mathrm{Phe}^{7}-$ $\mathrm{Arg}^{8}-\mathrm{Trp}^{9}-\mathrm{Gly}^{10}$ - $\mathrm{Lys}^{11}{ }^{11} \mathrm{Pro}^{12}-\mathrm{Val}^{13}-\mathrm{NH}_{2}$

NDP-MSH, $\left[\mathrm{Nle}^{4}, \mathrm{D}-\mathrm{Phe}^{7}\right] \alpha-\mathrm{MSH}$

MT-II, melanotan-II or Ac-Nle ${ }^{4}$-cyclo[ $\left[\mathrm{Asp}^{5}, \mathrm{Lys}^{10}\right] \alpha-\mathrm{MSH}(4-11) \mathrm{NH}_{2}$

THIQ, N-[(3R)-1,2,3,4-tetrahydroisoquinolinium-3-ylcarbonyl]-(1R)-1-(4-chlorobenzyl)-2-

[4-cyclohexyl-4-(1H-1,2,4-triazol-1ylmethyl)piperidin -1-yl]-2-oxoethylamine

MB243, (2S)-N-[(1R)-2-[4-cyclohexyl-4-[[(1,1-dimethylethyl)amino]carbonyl]-1-

piperidinyl]-1-[(4-fluorophenyl)methyl]-2-oxoethyl]-4-methyl-2-piperazinecarboxamide

AGRP, Agouti-related protein

\section{References}

1. Gantz I, Fong TM. The melanocortin system. Am. J. Physiol. Endocrinol. Metab 2003;284:E468-74. [PubMed: 12556347]

2. Hruby VJ, Wilkes BC, Hadley ME, Al-Obeidi F, Sawyer TK, Staples DJ, de Vaux AE, Dym O, Castrucci AM, Hintz MF, Riehm JP, Rao KRJ. alpha-Melanotropin: the minimal active sequence in the frog skin bioassay. J. Med. Chem 1987;30:2126-2130. [PubMed: 2822931]

3. Wikberg JE, Muceniece R, Mandrika I, Prusis P, Lindblom J, Post C, Skottner A. New aspects on the melanocortins and their receptors. Pharmacol. Res 2000;42:393-420. [PubMed: 11023702]

4. Watson, S.; Arkinstall, S. The G-Protein Linked Receptor Facts Book. Academic Press; San Diego: 1994. p. 1-294.

5. Haqq AM, Rene P, Kishi T, Khong K, Lee CE, Liu H, Friedman JM, Elmquist JK, Cone RD. Characterization of a novel binding partner of the melanocortin-4 receptor: attractin-like protein. Biochem. J 2003;376:595-605. [PubMed: 14531729]

6. Mountjoy KG, Kong PL, Taylor JA, Willard DH, Wilkison WO. Melanocortin receptor-mediated mobilization of intracellular free calcium in HEK293 cells. Physiol. Genomics 2001;5:11-19. [PubMed: 11161002]

7. MacNeil DJ, Howard AD, Guan X, Fong TM, Nargund RP, Bednarek MA, Goulet MT, Weinberg DH, Strack AM, Marsh DJ, Chen HY, Shen CP, Chen AS, Rosenblum CI, MacNeil T, Tota M, MacIntyre ED, Van der Ploeg LH. The role of melanocortins in body weight regulation: opportunities for the treatment of obesity. Eur. J. Pharmacol 2002;440:141-157. [PubMed: 12007532]

8. Vergoni AV, Bertolini A. Role of melanocortins in the central control of feeding. Eur. J. Pharmacol 2000;405:25-32. [PubMed: 11033311]

9. Van der Ploeg LH, Martin WJ, Howard AD, Nargund RP, Austin CP, Guan X, Drisko J, Cashen D, Sebhat I, Patchett AA, Figueroa DJ, DiLella AG, Connolly BM, Weinberg DH, Tan CP, Palyha OC, Pong SS, MacNeil T, Rosenblum C, Vongs A, Tang R, Yu H, Sailer AW, Fong TM, Huang C, Tota MR, Chang RS, Stearns R, Tamvakopoulos C, Christ G, Drazen DL, Spar BD, Nelson RJ, MacIntyre DE. A role for the melanocortin 4 receptor in sexual function. Proc. Natl. Acad. Sci. U. S. A 2002;99:11381-11386. [PubMed: 12172010]

10. Lubrano-Berthelier C, Cavazos M, Dubern B, Shapiro A, Stunff CL, Zhang S, Picart F, Govaerts C, Froguel P, Bougneres P, Clement K, Vaisse C. Molecular genetics of human obesity-associated MC4R mutations. Ann. N. Y. Acad. Sci 2003;994:49-57. [PubMed: 12851297]

11. Yeo GS, Lank EJ, Farooqi IS, Keogh J, Challis BG, O'Rahilly S. Mutations in the human melanocortin-4 receptor gene associated with severe familial obesity disrupts receptor function through multiple molecular mechanisms. Hum. Mol. Genet 2003;12:561-574. [PubMed: 12588803]

12. Tao YX, Segaloff DL. Functional characterization of melanocortin-4 receptor mutations associated with childhood obesity. Endocrinology 2003;144:4544-4551. [PubMed: 12959994]

13. Siegrist W, Drozdz R, Cotti R, Willard DH, Wilkison WO, Eberle AN. Interactions of alphamelanotropin and agouti on B16 melanoma cells: evidence for inverse agonism of agouti. J. Recept. Signal. Transduct. Res 1997;17:75-98. [PubMed: 9029482]

14. Dinulescu DM, Cone RD. Agouti and agouti-related protein: analogues and contrasts. J Biol Chem 2000;275:6695-6698. [PubMed: 10702221] 
15. Nijenhuis WA, Oosterom J, Adan RA. AgRP(83-132) acts as an inverse agonist on the humanmelanocortin-4 receptor. Mol. Endocrinol 2001;15:164-171. [PubMed: 11145747]

16. Haskell-Luevano C, Monck EK. Agouti-related protein functions as an inverse agonist at a constitutively active brain melanocortin-4 receptor. Regu.1 Pept 2001;99:1-7.

17. Chai BX, Neubig RR, Millhauser GL, Thompson DA, Jackson PJ, Barsh GS, Dickinson CJ, Li JY, Lai YM, Gantz I. Inverse agonist activity of agouti and agouti-related protein. Peptides 2003;24:603609. [PubMed: 12860205]

18. Sebhat IK, Martin WJ, Ye Z, Barakat K, Mosley RT, Johnston DB, Bakshi R, Palucki B, Weinberg DH, MacNeil T, Kalyani RN, Tang R, Stearns RA, Miller RR, Tamvakopoulos C, Strack AM, McGowan E, Cashen DE, Drisko JE, Hom GJ, Howard AD, MacIntyre DE, van der Ploeg LH, Patchett AA, Nargund RP. Design and pharmacology of N-[(3R)-1,2,3,4-tetrahydroisoquinolinium3-ylcarbonyl]-(1R)-1-(4-chlorobenzyl)- 2-[4-cyclohexyl-4-(1H-1,2,4-triazol-1-ylmethyl) piperidin-1-yl]-2-oxoethylamine (1), a potent, selective, melanocortin subtype-4 receptor agonist. J. Med. Chem 2002;45:4589-4593. [PubMed: 12361385]

19. Palucki BL, Park MK, Nargund RP, Ye Z, Sebhat IK, Pollard PG, Kalyani RN, Tang R, Macneil T, Weinberg DH, Vongs A, Rosenblum CI, Doss GA, Miller RR, Stearns RA, Peng Q, Tamvakopoulos C, McGowan E, Martin WJ, Metzger JM, Shepherd CA, Strack AM, Macintyre DE, Van der Ploeg LH, Patchett AA. Discovery of (2S)-N-[(1R)-2-[4-cyclohexyl-4-[[(1,1-dimethylethyl)amino] carbonyl]-1-piperidinyl]-1-[(4-fluorophenyl)methyl]-2-oxoethyl]-4-methyl-2piperazinecarboxamide (MB243), a potent and selective melanocortin subtype-4 receptor agonist. Bioorg. Med. Chem. Lett 2005;15:171-175. [PubMed: 15582434]

20. Wisse BE, Schwartz MW, Cummings DE. Melanocortin signaling and anorexia in chronic disease states. Ann. N. Y. Acad. Sci 2003;994:275-281. [PubMed: 12851326]

21. Willoughby CA, Hutchins SM, Rosauer KG, Dhar MJ, Chapman KT, Chicchi GG, Sadowski S, Weinberg DH, Patel S, Malkowitz L, Di Salvo J, Pacholok SG, Cheng K. Combinatorial synthesis of 3-(amidoalkyl) and 3-(aminoalkyl)-2-arylindole derivatives: discovery of potent ligands for a variety of G-protein coupled receptors. Bioorg Med. Chem. Lett 2002;12:93-96. [PubMed: 11738581]

22. Bondensgaard K, Ankersen M, Thogersen H, Hansen BS, Wulff BS, Bywater RP. Recognition of privileged structures by G-protein coupled receptors. J. Med. Chem 2004;47:888-899. [PubMed: 14761190]

23. Palczewski K, Kumasaka T, Hori T, Behnke CA, Motoshima H, Fox BA, Le Trong I, Teller DC, Okada T, Stenkamp RE, Yamamoto M, Miyano M. Crystal structure of rhodopsin: a G proteincoupled receptor. Science 2000;289:739-745. [PubMed: 10926528]

24. Li J, Edwards PC, Burghammer M, Villa C, Schertler GF. Structure of bovine rhodopsin in a trigonal crystal form. J. Mol. Biol 2004;343:1409-1438. [PubMed: 15491621]

25. John B, Sali A. Comparative protein structure modeling by iterative alignment, model building and model assessment. Nucleic Acids Res 2003;31:3982-3992. [PubMed: 12853614]

26. Oliveira L, Hulsen T, Lutje Hulsik D, Paiva AC, Vriend G. Heavier-than-air flying machines are impossible. FEBS Lett 2004;564:269-273. [PubMed: 15111108]

27. Farrens DL, Altenbach C, Yang K, Hubbell WL, Khorana HG. Requirement of rigid-body motion of transmembrane helices for light activation of rhodopsin. Science 1996;274:768-770. [PubMed: 8864113]

28. Halperin I, Ma B, Wolfson H, Nussinov R. Principles of docking: An overview of search algorithms and a guide to scoring functions. Proteins 2002;47:409-443. [PubMed: 12001221]

29. Pogozheva ID, Lomize AL, Mosberg HI. The transmembrane 7 alpha-bundle of rhodopsin: distance geometry calculations with hydrogen bonding constraints. Biophys. J 1997;72:1963-1985. [PubMed: 9129801]

30. Fowler C, Pogozheva ID, LeVine H III, Mosberg HI. Refinement of a homology model of the $\mu$ opioid receptor using distance constraints from intrinsic and engineered zinc-binding sites. Biochemistry 2004;43:8700-8710. [PubMed: 15236578]

31. Fowler CB, Pogozheva ID, Lomize AL, Levine H 3rd, Mosberg HI. Complex of an Active mu-Opioid Receptor with a Cyclic Peptide Agonist Modeled from Experimental Constraints. Biochemistry 2004;43:15796-15810. [PubMed: 15595835] 
32. Pogozheva ID, Przydzial MJ, Mosberg HI. Homology modeling of opioid receptor-ligand complexes using experimental constraints. AAPS J 2005;7, in press.

33. Chai B-X, Pogozheva ID, Lai Y-M, Li J-Y, Neubig RR, Mosberg HI, Gantz I. Receptor-antagonist interactions in the complexes of agouti and agouti-related protein with human melanocortin 1 and 4 receptors. Biochemistry 2005;44:3418-3431. [PubMed: 15736952]

34. Meng EC, Bourne HR. Receptor activation: what does the rhodopsin structure tell us? Trends Pharmacol Sci 2001;22:587-593. [PubMed: 11698103]

35. Karnik SS, Gogonea C, Patil S, Saad Y, Takezako T. Activation of G-protein-coupled receptors: a common molecular mechanism. Trends Endocrinol Metab 2003;14:431-437. [PubMed: 14580763]

36. Hadley ME, Anderson B, Heward CB, Sawyer TK, Hruby VJ. Calcium-dependent prolonged effects on melanophores of [4-norleucine, 7-D-phenylalanine]-alpha-melanotropin. Science 1981;213:1025-1027. [PubMed: 6973820]

37. Yang Y-K, Fong T, Dickinson CJ, Li J-Y, Tota M, Van der Ploeg LTH, Gantz I. Molecular determinants of ligand binding to the human melanocortin-4 receptor. Biochemistry 2000;39:1490014911. [PubMed: 11101306]

38. Yang Y-K, Dickinson C, Haskell-Luevano C, Gantz I. Molecular basis for the interaction of melanocortin peptides with the human melanocortin-1 receptor ( $\alpha$-MSH receptor). J. Biol. Chem 1997;272:23000-23010. [PubMed: 9287296]

39. DeBlasi A, O’Reilly K, Motulsky HJ. Calculating receptor number from binding experiments using same compound as radioligand and competitor. Trends Pharmacol. Sci 1989;10:227-229. [PubMed: 2773043]

40. Pogozheva ID, Lomize AL, Mosberg HI. Opioid receptor three-dimensional structures from distance geometry calculations with hydrogen bonding constraints. Biophys J 1998;75:612-634. [PubMed: 9675164]

41. Güntert P, Wüthrich K. Improved efficiency of protein structure calculations from NMR data using the program DIANA with redundant dihedral angle constraints. J. Biomol. NMR 1991;1:447-456. [PubMed: 1841711]

42. Lagerstrom MC, Klovins J, Fredriksson R, Fridmanis D, Haitina T, Ling MK, Berglund MM, Schioth HB. High affinity agonistic metal ion binding sites within the melanocortin 4 receptor illustrate conformational change of transmembrane region 3. J. Biol. Chem 2003;278:51521-51526. [PubMed: 14523020]

43. Sawyer TK, Hruby VJ, Darman PS, Hadley ME. [half-Cys4,half-Cys10]-alpha-Melanocytestimulating hormone: a cyclic alpha-melanotropin exhibiting superagonist biological activity. Proc. Natl. Acad. Sci. U. S. A 1982;79:1751-1755. [PubMed: 6281785]

44. al-Obeidi F, Hadley ME, Pettitt BM, Hruby VJ. Design of a new class of superpotent cyclic $\alpha$ melanotropins based on quenched dynamic simulations. J. Amer. Chem. Soc 1989;111:3413-3416.

45. Brooks BR, Bruccoleri ER, Olafson ER, States DJ, Swaminathan S, Karplus M. CHARMM: a program for macromolecular energy, minimization and dynamics calculations. J. Comput. Chem 1983;4:187-217.

46. Nickolls SA, Cismowski MI, Wang X, Wolff M, Conlon PJ, Maki RA. Molecular determinants of melanocortin 4 receptor ligand binding and MC4/MC3 receptor selectivity. J. Pharmacol. Exp. Ther 2003;304:1217-27. [PubMed: 12604699]

47. Haskell-Luevano C, Nikiforovich G, Sharma SD, Yang YK, Dickinson C, Hruby VJ, Gantz I. Biological and conformational examination of stereochemical modifications using the template melanotropin peptide, Ac-Nle-c[Asp-His-Phe-Arg-Trp-Ala-Lys]-NH2, on human melanocortin receptors. J. Med. Chem 1997;40:1738-1748. [PubMed: 9171884]

48. Mutulis F, Yahorava S, Mutule I, Yahorau A, Liepinsh E, Kopantshuk S, Veiksina S, Tars K, Belyakov S, Mishnev A, Rinken A, Wikberg JE. New substituted piperazines as ligands for melanocortin receptors. Correlation to the X-ray structure of "THIQ". J. Med.Chem 2004;47:4613-4626. [PubMed: 15317471]

49. Holder JR, Haskell-Luevano C. Melanocortin tetrapeptides modified at the N-terminus, His, Phe, Arg, and Trp positions. Ann. N. Y. Acad. Sci 2003;994:36-48. [PubMed: 12851296] 
50. Sawyer TK, Sanfilippo PJ, Hruby VJ, Engel MH, Heward CB, Burnett JB, Hadley ME. 4-Norleucine, 7-D-phenylalanine-alpha-melanocyte-stimulating hormone: a highly potent alpha-melanotropin with ultralong biological activity. Proc. Natl. Acad. Sci. U.S.A 1980;77:5754-5758. [PubMed: 6777774]

51. Prusis P, Frandberg PA, Muceniece R, Kalvinsh I, Wikberg JE. A three dimensional model for the interaction of MSH with the melanocortin-1 receptor. Biochem. Biophys. Res. Commun 1995;210:205-10. [PubMed: 7741742]

52. Prusis P, Schioth HB, Muceniece R, Herzyk P, Afshar M, Hubbard RE, Wikberg JE. Modeling of the three-dimensional structure of the human melanocortin 1 receptor, using an automated method and docking of a rigid cyclic melanocyte-stimulating hormone core peptide. J. Mol. Graph. Model 1997;15:307-317. [PubMed: 9640562], 334.

53. Prusis P, Muceniece R, Andersson P, Post C, Lundstedt T, Wikberg JE. PLS modeling of chimeric MS04/MSH-peptide and MC1/MC3-receptor interactions reveals a novel method for the analysis of ligand-receptor interactions. Biochim. Biophys. Acta 2001;1544:350-357. [PubMed: 11341944]

54. Hruby VJ, Lu D, Sharma SD, Castrucci AL, Kesterson RA, al-Obeidi FA, Hadley ME, Cone RD. Cyclic lactam alpha-melanotropin analogues of Ac-Nle4-cyclo[Asp5, D-Phe7,Lys10] alphamelanocyte-stimulating hormone-(4-10)-NH2 with bulky aromatic amino acids at position 7 show high antagonist potency and selectivity at specific melanocortin receptors. J Med Chem 1995;38:3454-3461. [PubMed: 7658432]

55. Ruprecht JJ, Mielke T, Vogel R, Villa C, Schertler GF. Electron crystallography reveals the structure of metarhodopsin I. EMBO J 2004;23:3609-3620. [PubMed: 15329674]

56. Prabhu NV, Perkyns JS, Pettitt BM. Modeling of alpha-MSH conformations with implicit solvent. J. Pept. Res 1999;54:394-407. [PubMed: 10563505]

57. Nikiforovich GV, Sharma SD, Hadley ME, Hruby VJ. Studies of conformational isomerism in alphamelanocyte stimulating hormone by design of cyclic analogues. Biopolymers 1998;46:155-167. [PubMed: 9699465]

58. Ying J, Kover KE, Gu X, Han G, Trivedi DB, Kavarana MJ, Hruby VJ. Solution structures of cyclic melanocortin agonists and antagonists by NMR. Biopolymers 2003;71:696-716. [PubMed: 14991679]

59. Cai M, Cai C, Mayorov AV, Xiong C, Cabello CM, Soloshonok VA, Swift JR, Trivedi D, Hruby VJ. Biological and conformational study of beta-substituted prolines in MT-II template: steric effects leading to human MC5 receptor selectivity. J. Pept. Res 2004;63:116-131. [PubMed: 15009533]

60. Schioth HB, Mutulis F, Muceniece R, Prusis P, Wikberg JE. Discovery of novel melanocortin4 receptor selective MSH analogues. Br. J. Pharmacol 1998;124:75-82. [PubMed: 9630346]

61. Kask A, Mutulis F, Muceniece R, Pahkla R, Mutule I, Wikberg JE, Rago L, Schioth HB. Discovery of a novel superpotent and selective melanocortin-4 receptor antagonist (HS024): evaluation in vitro and in vivo. Endocrinology 1998;139:5006-5014. [PubMed: 9832440]

62. Sugg EE, Castrucci AM, Hadley ME, van Binst G, Hruby VJ. Cyclic lactam analogues of Ac-[Nle4] alpha-MSH4-11-NH2. Biochemistry 1988;27:8181-8188. [PubMed: 2852955]

63. Haskell-Luevano C, Lim S, Yuan W, Cone RD, Hruby VJ. Structure activity studies of the melanocortin antagonist SHU9119 modified at the 6, 7, 8, and 9 positions. Peptides 2000;21:49-57. [PubMed: 10704719]

64. Nijenhuis WA, Kruijtzer JA, Wanders N, Vrinten DH, Garner KM, Schaaper WM, Meloen RH, Gispen WH, Liskamp RM, Adan RA. Discovery and in vivo evaluation of new melanocortin-4 receptor-selective peptides. Peptides 2003;24:271-280. [PubMed: 12668212]

65. Bednarek MA, MacNeil T, Kalyani RN, Tang R, Van der Ploeg LH, Weinberg DH. Analogs of lactam derivatives of alpha-melanotropin with basic and acidic residues. Biochem. Biophys. Res. Commun 2000;272:23-28. [PubMed: 10872798]

66. Oosterom J, Burbach JP, Gispen WH, Adan RA. Asp10 in Lys-gamma2-MSH determines selective activation of the melanocortin MC3 receptor. Eur. J. Pharmacol 1998;354:R9-11. [PubMed: 9726642]

67. Yang Y, Chen M, Lai Y, Gantz I, Georgeson KE, Harmon CM. Molecular determinants of human melanocortin-4 receptor responsible for antagonist SHU9119 selective activity. J. Biol. Chem 2002;277:20328-20335. [PubMed: 11912210] 
68. Holder JR, Xiang Z, Bauzo RM, Haskell-Luevano C. Structure-activity relationships of the melanocortin tetrapeptide Ac-His-D-Phe-Arg-Trp-NH2 at the mouse melanocortin receptors. 4. Modifications at the Trp position. J. Med. Chem 2002;45:5736-5744. [PubMed: 12477357]

69. Schioth HB, Petersson S, Muceniece R, Szardenings M, Wikberg JE. Deletions of the N-terminal regions of the human melanocortin receptors. FEBS Lett 1997;410:223-228. [PubMed: 9237634]

70. Srinivasan S, Lubrano-Berthelier C, Govaerts C, Picard F, Santiago P, Conklin BR, Vaisse C. Constitutive activity of the melanocortin- 4 receptor is maintained by its $\mathrm{N}$-terminal domain and plays a role in energy homeostasis in humans. J. Clin. Invest 2004;114:1158-1164. [PubMed: 15489963]

71. Dyck B, Parker J, Phillips T, Carter L, Murphy B, Summers R, Hermann J, Baker T, Cismowski M, Saunders J, ad Goodfellow V. Aryl piperazine melanocortin MC4 receptor agonists. Bioorg. Med. Chem. Lett 2003;13:3793-3796. [PubMed: 14552781]

72. Herpin TF, Yu G, Carlson KE, Morton GC, Wu X, Kang L, Tuerdi H, Khanna A, Tokarski JS, Lawrence RM, Macor JE. Discovery of tyrosine-based potent and selective melanocortin-1 receptor small-molecule agonists with anti-inflammatory properties. Med. Chem 2003;46:1123-1126.

73. Pan K, Scott MK, Lee DH, Fitzpatrick LJ, Crooke JJ, Rivero RA, Rosenthal DI, Vaidya AH, Zhao B, Reitz AB. 2,3-Diaryl-5-anilino[1,2,4]thiadiazoles as melanocortin MC4 receptor agonists and their effects on feeding behavior in rats. Bioorg. Med. Chem 2003;11:185-192. [PubMed: 12470712]

74. Ujjainwalla F, Warner D, Walsh TF, Wyvratt MJ, Zhou C, Yang L, Kalyani RN, MacNeil T, Van der Ploeg LH, Rosenblum CI, Tang R, Vongs A, Weinberg DH, Goulet MT. Design and syntheses of melanocortin subtype-4 receptor agonists: evolution of the pyridazinone archetype. Bioorg. Med. Chem. Lett 2003;13:4431-4435. [PubMed: 14643340]

75. Richardson TI, Ornstein PL, Briner K, Fisher MJ, Backer RT, Biggers CK, Clay MP, Emmerson PJ, Hertel LW, Hsiung HM, Husain S, Kahl SD, Lee JA, Lindstrom TD, Martinelli MJ, Mayer JP, Mullaney JT, O’Brien TP, Pawlak JM, Revell KD, Shah J, Zgombick JM, Herr RJ, Melekhov A, Sampson PB, King CH. Synthesis and structure-activity relationships of novel arylpiperazines as potent and selective agonists of the melanocortin subtype-4 receptor. J. Med. Chem 2004;47:744755. [PubMed: 14736255]

76. Holst B, Elling CE, Schwartz TW. Metal ion-mediated agonism and agonist enhancement in melanocortin MC1 and MC4 receptors. J. Biol. Chem 2002;277:47662-47670. [PubMed: 12244039]

77. Holst B, Schwartz TW. Molecular mechanism of agonism and inverse agonism in the melanocortin receptors: $\mathrm{Zn}(2+)$ as a structural and functional probe. Ann. N. Y. Acad. Sci 2003;994:1-11. [PubMed: 12851292]

78. Ballesteros JA, Weinstein H. Integrated methods for the construction of three-dimentional models and computational probing of structure-function relations in G-protein coupled receptors. Methods Neurosci 1995;25:366-428. 


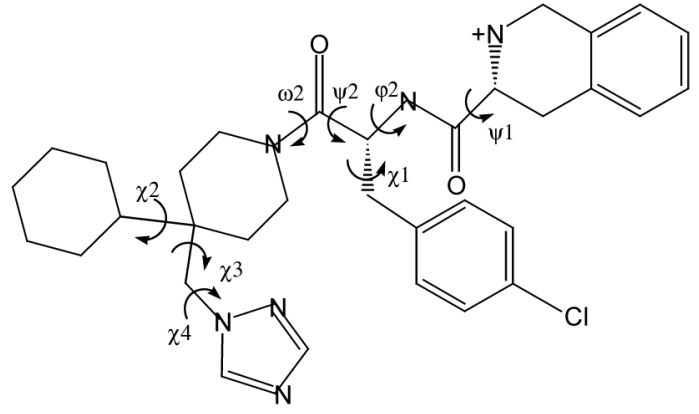

THIQ

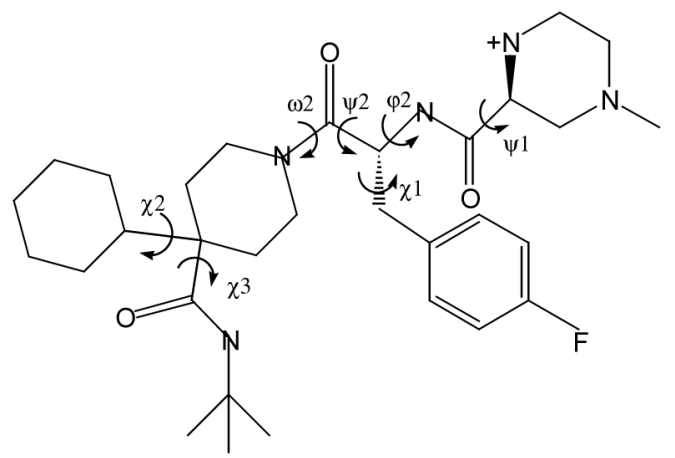

MB243

Figure 1.

Structures of hMC4R small-molecule agonists. 


\begin{tabular}{|c|c|c|}
\hline & $N-t \epsilon$ & erminus TMH1 \\
\hline RHODOPSIN & 33 & EPWQFSMLAAYMFLLIMLGFPINFLTLYVTVQHKKLRT \\
\hline \multirow{2}{*}{ hMC4R } & 40 & CYEQLFVSPEVFVTLGVISLLENILVIVAIAKNKNLHS \\
\hline & & TMH2 \\
\hline RHODOPSIN & 71 & PLNYILLNLAVADLFMVFGGFTTTLYTSLHGYFVF - - - - - - GPTG \\
\hline \multirow[t]{2}{*}{ hMC4R } & 78 & $\overline{\text { PMYFFICSLAVADMLVSV-SNGSETIIITLLNSTDTD-AQSFTVNI }}$ \\
\hline & & TMH3 \\
\hline RHODOPSIN & 110 & CNLEGFFATLGGEIALWSLVVLAIERYVVVCKPMSNFRFG- \\
\hline \multirow[t]{2}{*}{$\mathrm{hMC} 4 \mathrm{R}$} & 122 & DNVIDSVICSSLLASICSLLSIAVDRYFTIFYALQYHNIMT \\
\hline & & TMH4 \\
\hline RHODOPSIN & 150 & ENHAIMGVAFTWVMALACAAPPLVGWSRYI PEGMQCSCGIDYYTPHEETN \\
\hline \multirow{2}{*}{$\mathrm{hMC} 4 \mathrm{R}$} & 163 & VKRVGIIISCIWAACTVSGILFIIYS \\
\hline & & TMH5 \\
\hline RHODOPSIN & 200 & NESFVIYMFVVHFI I PLIVIFFCYGQLVFTVKEAAAQQQE - - - \\
\hline \multirow[t]{2}{*}{$\mathrm{hMC} 4 \mathrm{R}$} & 189 & 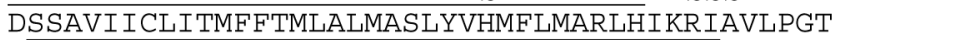 \\
\hline & & TMH6 \\
\hline RHODOPSIN & 240 & SATTQKAEKEVTRMVIIMVIAFLICWLPYAGVAFYIFTHQ---GSDFGP \\
\hline \multirow[t]{2}{*}{$\mathrm{hMC} 4 \mathrm{R}$} & 233 & GAIRQGANMKGAITLTILIGVFVVCWAPFFLHLIFYISCPQNPYCVCFM \\
\hline & & $\begin{array}{lll}\text { TMH7 } & \text { * } & \text { IL }-4\end{array}$ \\
\hline RHODOPSIN & 286 & IFMTIPAFFAKTSAVYNPVIYIMMNKQFRNCMVTTLCCGK \\
\hline hMC4R & 282 & $\overline{\text { SHFNLYLILIMCNS I IDPLIYALRS }} \overline{Q E L R K T F K E I ~ I C C Y P ~}$ \\
\hline
\end{tabular}

Figure 2.

Sequence alignments of bovine rhodopsin with human MC4R. Underlined characters represent residues from $\alpha$-helices, mutated residues are colored by red. The most conserved residue in each TMH $(1.50,2.50,3.50,4.50,5.50,6.50,7.50$, in the nomenclature of reference 78$)$ of rhodopsin-like GPCR is indicated with an asterisk. 

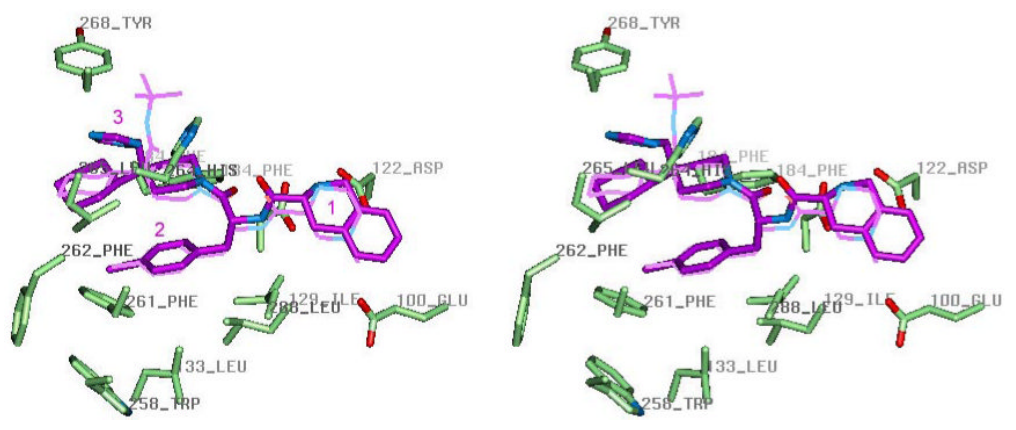

Figure 3.

Stereoview of small-molecule agonist THIQ (purple) inside the binding pocket of the hMC4R active conformation model. The mutated residues of hMC4R are shown in the licorice representation colored by element. MB243 is shown in thin purple line for comparison. The central part of both ligands, a 4-substituted ${ }_{\mathrm{D}}-\mathrm{Phe}^{2}$, occupies the bottom of the cavity formed by $\mathrm{Ile}^{129}, \mathrm{Leu}^{133}, \mathrm{Trp}^{258}, \mathrm{Phe}^{261}$, and $\mathrm{Leu}^{288}$, the positively charged amino group of the first residue is close to negatively charged $\mathrm{Glu}^{100}, \mathrm{Asp}^{122}$, and $\mathrm{Asp}^{126}$, and $\mathrm{Asp}^{126}$ also forms and $\mathrm{H}$-bond with the backbone amide group of ${ }_{\mathrm{D}}-\mathrm{Phe}^{2}$; while the third residue mimic contacts with $\mathrm{Phe}^{184} \mathrm{Leu}^{265}$, and $\mathrm{Tyr}^{268}$, with its polar group interacting with $\mathrm{His}^{264}$. 

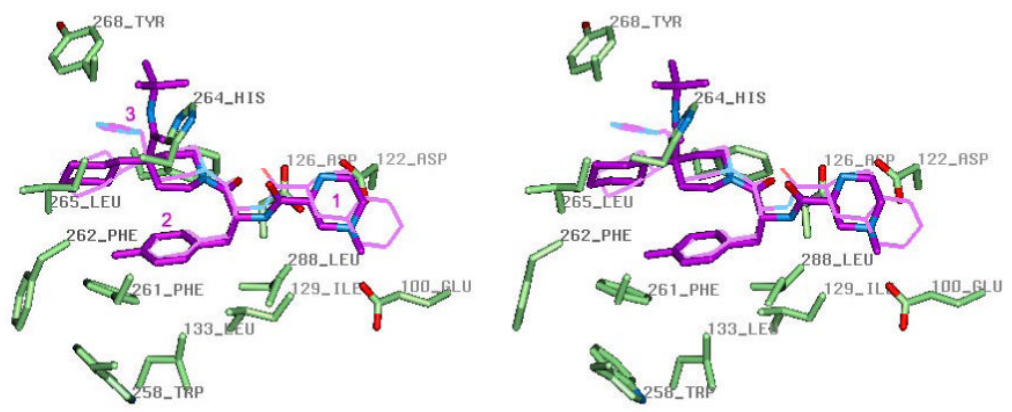

Figure 4.

Stereoview of small-molecule agonist MB243 (purple) inside the binding pocket of the hMC4R active conformation model. The mutated residues of hMC4R are shown in the licorice representation colored by element. THIQ is shown in thin purple line for comparison. See legend of Figure 3 for the description of the illustrated ligand-receptor interactions. 

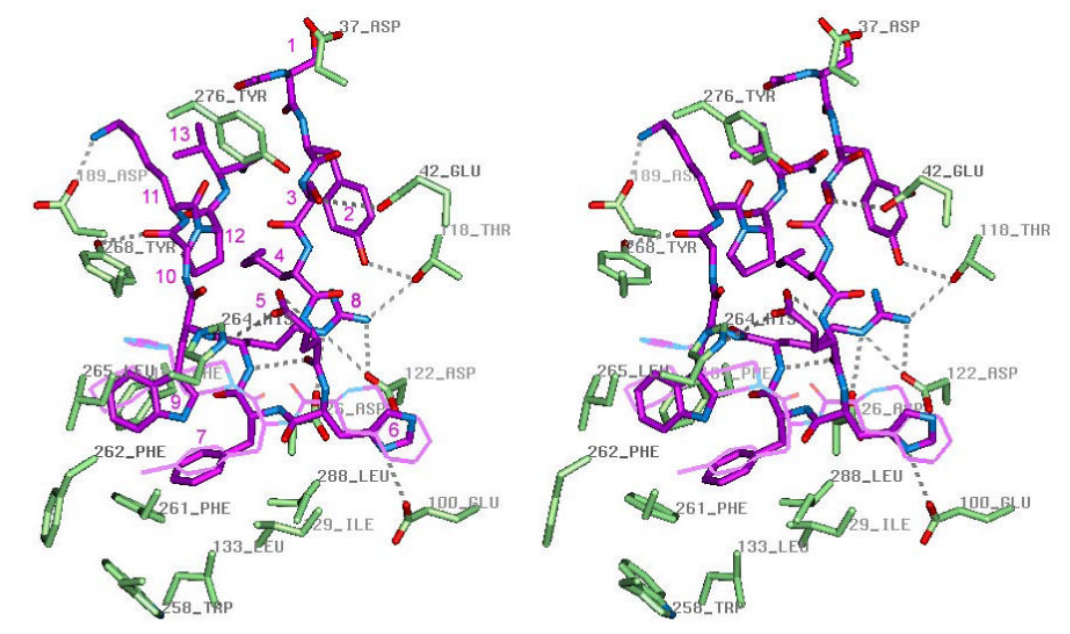

Figure 5.

Stereoview of peptide agonist NDP-MSH (purple) inside the binding pocket of the hMC4R active conformation model. The mutated hMC4R residues and residues forming H-bonds with peptide are shown in the licorice representation colored by element. THIQ is shown in thin purple line for comparison. The receptor-bound conformation of NDP-MSH represents a $\beta$ hairpin-like structure with a reverse turn spanning $\mathrm{His}^{6}$ and ${ }_{\mathrm{D}}-\mathrm{Phe}^{7}$, aromatic rings of ${ }_{\mathrm{D}}-\mathrm{Phe}^{7}$ and $\operatorname{Trp}^{9}$ forming stacking interactions, and polar residues $\mathrm{Glu}^{5}$ and $\mathrm{Arg}^{8}$ located on different sides of the $\beta$-hairpin. Inside the binding pocket, NDP-MSH forms at least nine $\mathrm{H}$-bonds with polar groups of the receptor (shown by dashed lines): $\mathrm{Tyr}^{2}$ hydroxyl with $\mathrm{Thr}^{118}$ hydroxyl, carboxylate group of $\mathrm{Asp}^{5}$ and backbone carbonyl of Trp ${ }^{9}$ with $\mathrm{His}^{264}$, imidazole of His ${ }^{6}$ with $\mathrm{Glu}^{100}$, guanidinium group of $\mathrm{Arg}^{8}$ with $\mathrm{Asp}^{122}$ and $\mathrm{Asp}^{126}$ carboxylate groups and hydroxyl of $\mathrm{Thr}^{118}$, backbone amide group of ${ }_{\mathrm{D}}-\mathrm{Phe}^{7}$ with $\mathrm{Asp}^{126}$ carboxylate, backbone carbonyl of Gly ${ }^{10}$ with Tyr $^{268}$ hydroxyl, and amine group of Lys ${ }^{11}$ with Asp ${ }^{189}$ carboxylate. Important hydrophobic interactions are formed between aromatic rings of ${ }_{\mathrm{D}}-\mathrm{Phe}^{7}$ and $\operatorname{Trp}^{9}$ of peptide agonist and non-polar binding pocket residues, $\mathrm{Ile}^{129}$, Leu ${ }^{133}, \mathrm{Phe}^{184}, \mathrm{Leu}^{265}, \mathrm{Trp}^{258}$, $\mathrm{Phe}^{261}, \mathrm{Leu}^{288}$. 
A

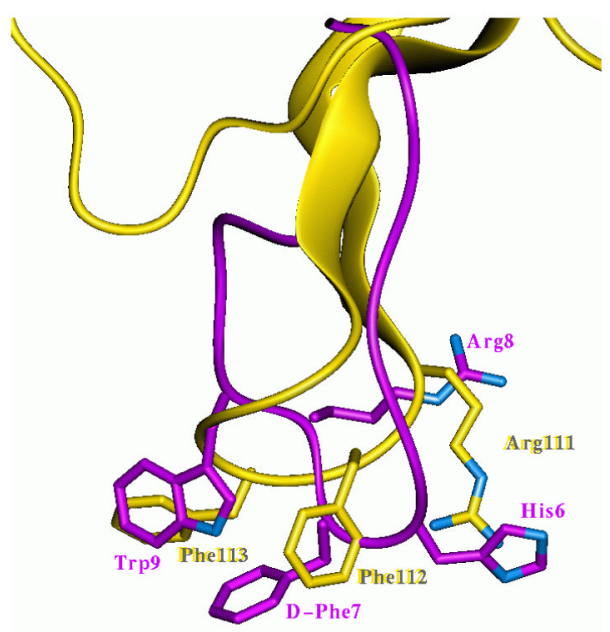

B

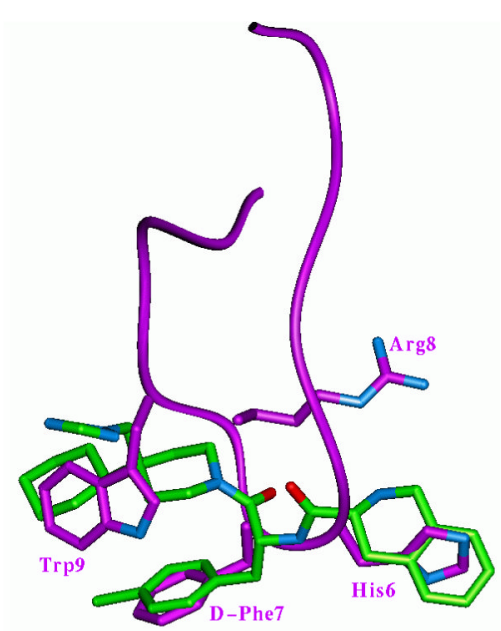

Figure 6.

A. Superposition of receptor-bound conformation of inverse agonist AGRP (87-132) (yellow) inside the model of hMC4R in the inactive state, and peptide agonist, NDP-MSH (purple) inside the model of hMC4R in the active state; B. Superposition of receptor-bound conformations of peptide agonist NDP-MSH (purple) and small-molecule agonist THIQ (green) inside the model of hMC4R in the active state. Core residues of AGRP (Arg ${ }^{111}$, $\mathrm{Phe}^{112}, \mathrm{Phe}^{113}$ ) and of NDP-MSH (His $\left.{ }^{6},{ }_{\mathrm{D}}-\mathrm{Phe}^{7}, \mathrm{Arg}^{8}, \mathrm{Trp}^{9}\right)$ are shown in the licorice representation. 


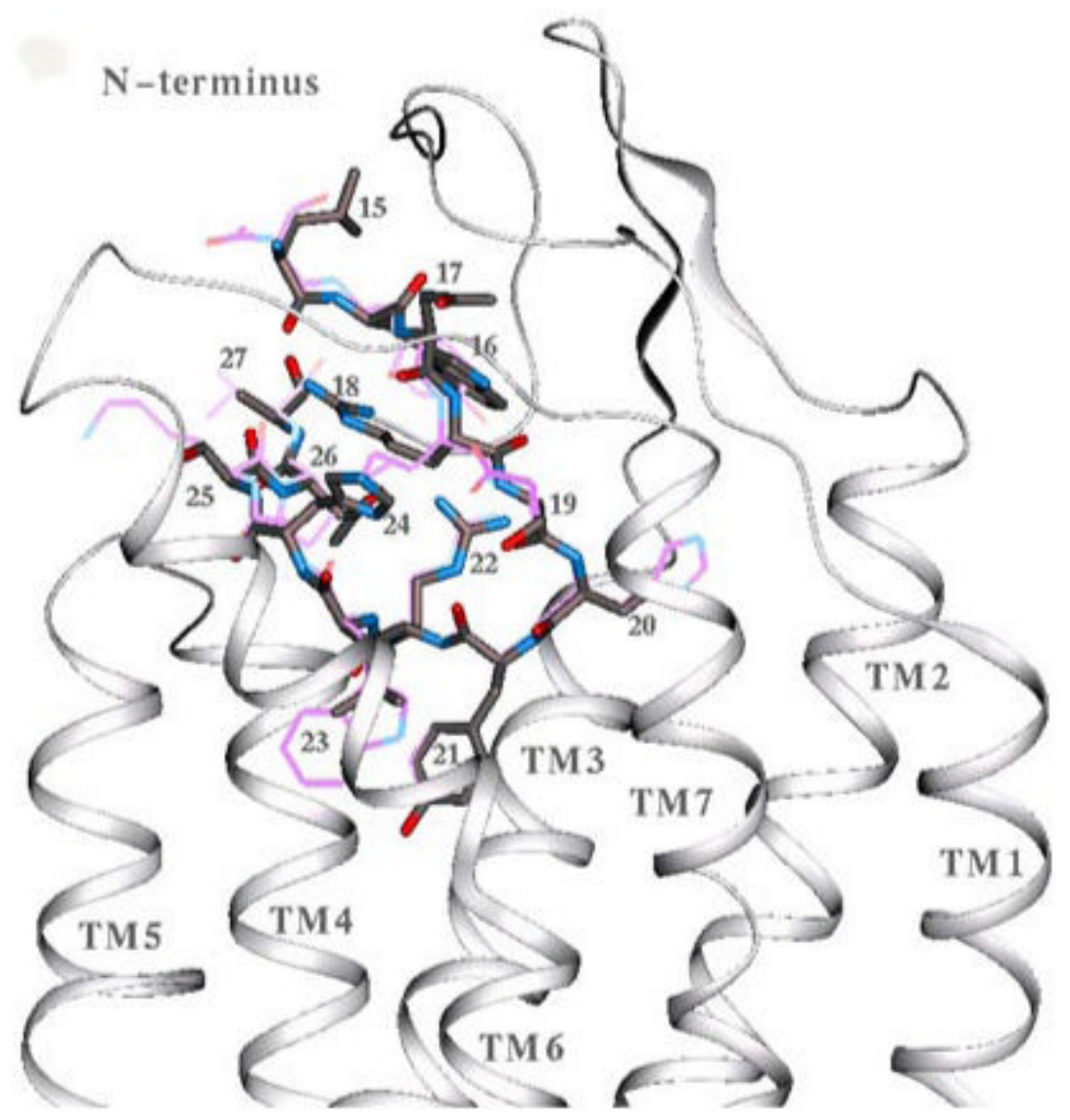

Figure 7.

Putative arrangement of the N-terminal fragment (15-27) inside the binding pocket of hMC4R, docked similarly to the peptide agonista-MSH (1-13). The N-terminal fragment is shown in the licorice representation colored by element, $\alpha-\mathrm{MSH}$ is shown by a thin purple line. The central tetrapeptide fragment of the N-terminal sequence ${ }^{20}$ SYRL structurally overlaps with ${ }^{6} \mathrm{HFRW}$ of the peptide agonist, $\alpha-\mathrm{MSH}$. 


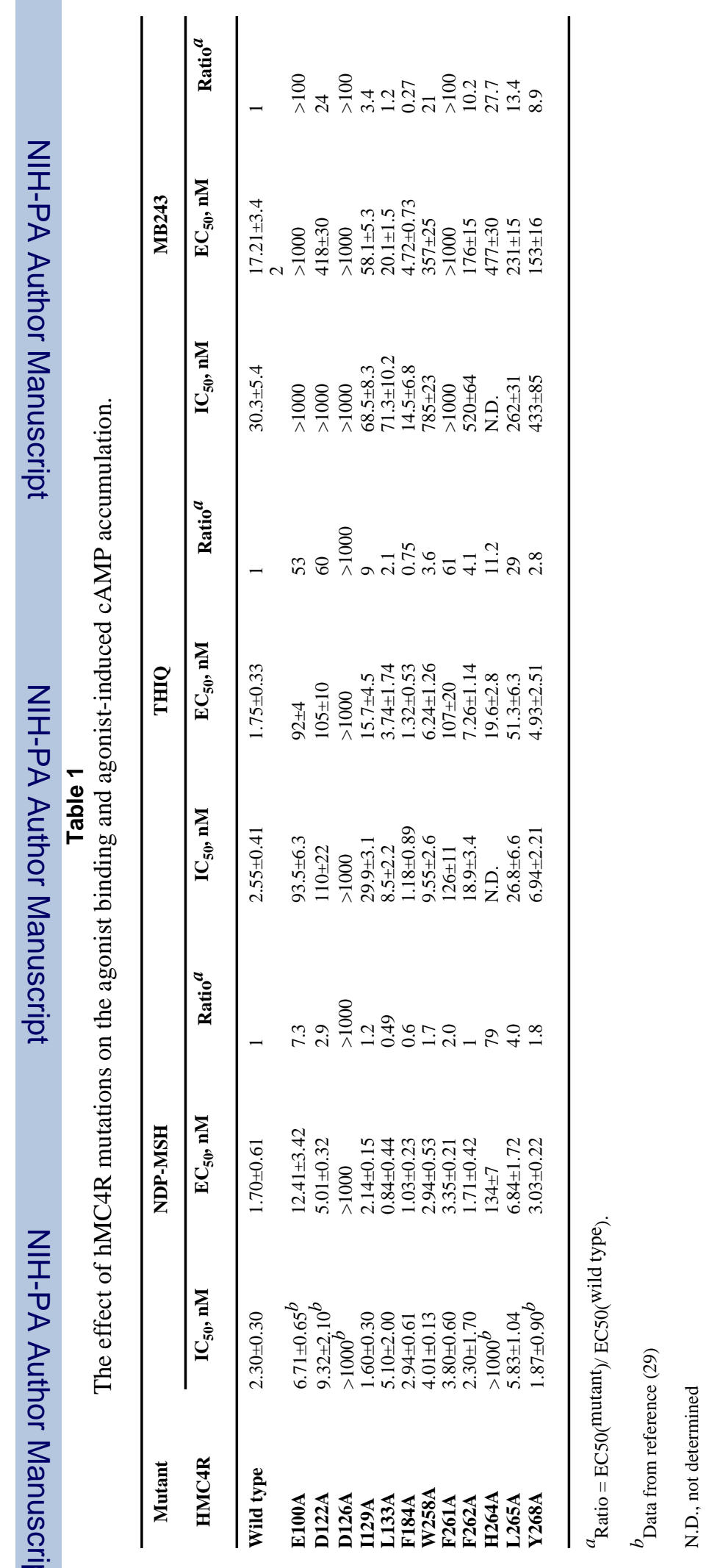




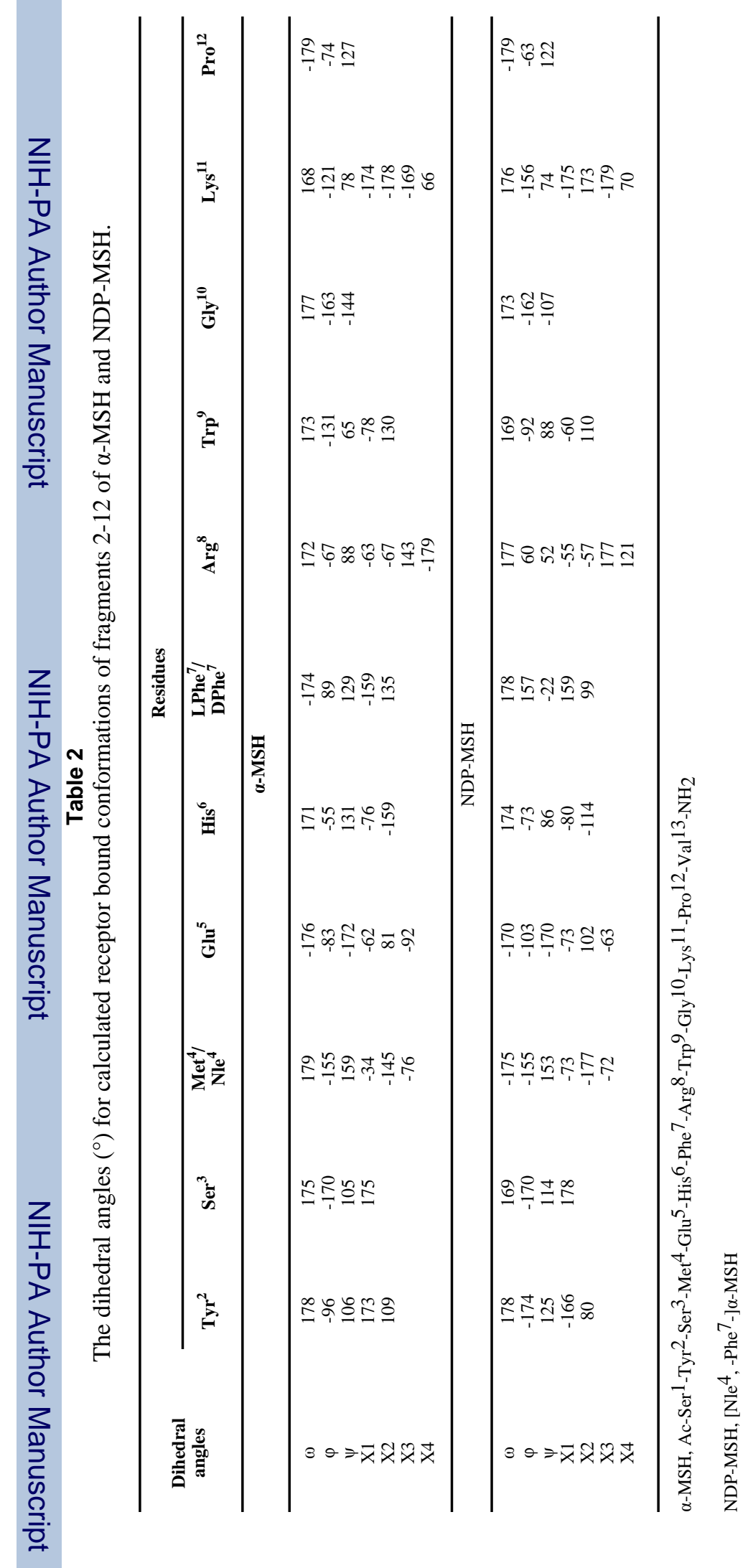

